\title{
Amyloid Hypothesis and Alzheimer's Disease
}

\author{
Xiaqin Sun and Yan Zhang \\ Laboratory of Neurobiology and State Key Laboratory of Biomembrane and \\ Membrane Biotechnology, College of Life Sciences, Peking University, Beijing, \\ China
}

\section{Introduction}

This chapter reviews the major hypotheses in Alzheimer's disease (AD) research with the focus on amyloid hypothsis. Since amyloid hypothesis of AD pathology was proposed, extracellular amyloid $\beta(\mathrm{A} \beta)$ toxicity and its role of inducing synaptic plasticity and memory function has been studying intensively. Accumulating evidence indicates that $A \beta$ also exists inside the neurons in AD. Intracellular $\mathrm{A} \beta$ has great impact on a variety of cellular events from protein degradation, axonal transport, neuronal firing, autophagy to apoptosis, suggesting an important role of $\mathrm{A} \beta$ in $\mathrm{AD}$ development, especially in the early stage. This chapter overviews the studies on the presence, production, metabolism and toxicity of extracellular and intracellular $A \beta$. Therapeutics targeting $A \beta$ could be a new and effective treatment for early AD.

\section{Overview of Alzheimer's disease}

Alzheimer's disease (AD) is a progressive neurodegenerative disorder characterized by agerelated impairment in cognition and memory. The first AD case was reported in 1907 in Germany by Dr. Alois Alzheimer of a middle-aged woman who developed memory deficits and progressive loss of cognitive abilities. Many AD patients show clinical symptoms of severe memory loss and progressive cognitive difficulty in their 60's or 70's except the familial AD (FAD) patients who usually show clinical symptoms in their 40's (Price and Sisodia, 1998). These clinical symptoms include abnormalities of learning, memory, problem solving, speaking, calculation, judgment and planning (McKhann et al., 1984). The development of $\mathrm{AD}$ is progressive and can sometimes last for over decades. The development of $\mathrm{AD}$ can be divided into three stages according to clinical symptoms (Boller et al., 2002). In the mild stage of $A D$, patients first lose their short-term memory. They tend to forget the recent events, while they still remember the events that happened many years ago. Simple calculation and daily organization become more and more difficult. They become more and more passive for social activities and some of them develop depression and anxiety. In this stage, most of the patients can still maintain normal daily activities. The mild stage usually lasts for 2-3 years (Boller et al., 2002). The second stage of AD is the moderate stage. In this stage, patients cannot recognize family members. They are not able to communicate well with others since they lose thought flow or words during speaking. The daily self-care and housekeeping events of patients require more and more help from 
others. Since the daily activities, such as feeding, cooking, dressing and bathing become more and more difficult, the patients are depressed and paranoid more easily (Boller et al., 2002). In the late stage of AD, patients completely lose the abilities to speak, solve problems and make decisions. Daily activities can be affected greatly and everyday life of patients totally depends on caregivers (Price and Sisodia, 1998; Boller et al., 2002).

\section{AD pathological hallmarks}

$\mathrm{AD}$ affects neurons in the neocortex, including the frontal lobe and the temporal lobe (Mann et al., 1985; Mesulam and Geula, 1988; Gomez-Isla et al., 1997), the entorhinal cortex and the hippocampus (Samuel et al., 1994; West et al., 1994; Gomez-Isla et al., 1997). Subcortical limbic areas such as the cholinergic neurons in the basal forebrain (Struble et al., 1986) and the neurons in the amygdala, the anterior nucleus of the thalamus, the raphe, and the locus coeruleus (Price and Sisodia, 1998), are also affected. It is suggested that the first area affected in the brain is the entorhinal cortex and then neurodegeneration progresses to the hippocampus and then to the cortex (Price and Sisodia, 1998).

\subsection{Senile plaques}

Senile plaques (SPs) are the extracellular proteinacous deposits found in AD patient brains. Deteriorated neurons are often seen near the SP area in the brain (McKhann et al., 1984; Morris et al., 1991; Defigueiredo et al., 1995; Price and Sisodia, 1998; Tseng et al., 1999; Urbanc et al., 1999; Alorainy, 2000). In the SPs, there are dystrophic neuritis. Astrocytes and microglia are often associating with the amyloid deposits (Defigueiredo et al., 1995; Tseng et al., 1999; Urbanc et al., 1999; Alorainy, 2000). The primary proteinacous material of SPs is amyloid $\beta$ peptide (A $\beta$ ), a fibrillar peptide containing 40 to 42 amino acids derived from amyloid precursor protein (APP) (Glenner and Wong, 1984; Masters et al., 1985; Mori et al., 1992; Roher et al., 1993). There are four types of SPs often found in AD brains according to morphology (Defigueiredo et al., 1995; Gearing et al., 1995; Tseng et al., 1999; Urbanc et al., 1999; Alorainy, 2000): (1) Diffuse plaques are usually 10-200 $\mu \mathrm{m}$ in diameter with irregular shapes, in which $A \beta$ is not aggregated into fibrils or deposits. Near these plaques, there are less NFTs and dystrophic neurites. The diffuse plaques are not detectable by Congo red or silver staining, but can be stained by $\mathrm{A} \beta$ antibodies. The diffuse plaques are close to neuronal cell bodies, that raises the possibility that the diffuse plaques may originate within the cell body as intracellular A $\beta$ peptides (D'Andrea et al., 2001). The diffuse plaques appear in the DS patients, younger AD patients and other head injury patients (Defigueiredo et al., 1995; Gearing et al., 1995; Tseng et al., 1999; Urbanc et al., 1999; Alorainy, 2000; D'Andrea et al., 2001). All the above evidence suggests that diffuse plaques might be the earliest amyloid aggregates appearing in $\mathrm{AD}$ development and the origin of these diffuse plaques might be intracellular amyloid. (2) Primitive plaques are 20$60 \mu \mathrm{m}$ in diameter, in which A $\beta$ starts to form fibrils and NFTs that are detectable near these plaques. The primitive plaques associate less with the neuronal cell bodies, but more with astrocytes and glial cells. The primitive plaques appear in the older AD patients (Defigueiredo et al., 1995; Gearing et al., 1995; Tseng et al., 1999; Urbanc et al., 1999; Alorainy, 2000). (3) Classic plaques are the most significant type of plaques in AD brains. These plaques are also $20-60 \mu \mathrm{m}$ in diameter and $\mathrm{A} \beta$ peptides form clearly visible aggregates and deposits of fibrils. These aggregates often induce a central dense core 
structure surrounded by dystrophic neurites and a large amount of glial cells. The classic plaques are located throughout the hippocampus and the neocortex in advanced and older AD patient brains (Defigueiredo et al., 1995; Gearing et al., 1995; Tseng et al., 1999; Urbanc et al., 1999; Alorainy, 2000). (4) Compact plaques are similar to the classic plaques, with 5$15 \mu \mathrm{m}$ in diameter, but lack the surrounding dystrophic neurites (Defigueiredo et al., 1995; Gearing et al., 1995; Tseng et al., 1999; Urbanc et al., 1999; Alorainy, 2000). Congo red and silver staining are the common cytochemical detectors for SPs. The Congo red dye forms non-polar hydrogen bonds with amyloid fibrils (Braak et al., 1989). The red to green birefringence occurs when viewed by polarized light due to parallel alignment of the dye molecules on the linearly arranged amyloid fibrils (Braak et al., 1989). Silver staining, on the other hand, detects pre-plaques or presumed early SPs, which cannot be stained by the conventional Congo red staining (Braak et al., 1989).

In addition to human, extracellular SPs are also found in other long-lived mammals, such as some non-human primates like Cheirogelidae, Callitricadae, Cebidae and Pogidae (Struble et al., 1984; Gearing et al., 1995; Gearing et al., 1997), domestic dogs (Cummings et al., 1996; Tekirian et al., 1996), cats (Cummings et al., 1996) and polar bears (Cork et al., 1988; Tekirian et al., 1996). However, common laboratory rats and mice do not have natural accumulation of amyloid with age (Jucker et al., 1994). SPs are often found in the amygdala, the hippocampus and the neocortex (Gearing et al., 1995).

\subsection{Neurofibrillary tangles}

In $\mathrm{AD}$ brains, besides SPs, another striking pathological feature is intracellular neurofibrillary tangles (NFTs). The affected neurons often show intracellular accumulations of single straight filaments and paired helical filaments and neuropil threads (Arnold et al., 1991; Braak and Braak, 1994; Gold, 2002). The major component of these poorly soluble filaments is hyperphosphorylated tau, a $68 \mathrm{kDa}$ microtubuleassociated protein (Lee et al., 1991; Gomez-Isla et al., 1996; Hardy, 2003; Roder, 2003). The diseases with tau-based neurofibrillary pathology include: AD, Down's syndrome (DS), amyotrophic lateral sclerosis/parkinsonism-dementia complex, Creutzfeldt-Jakob disease, frontotemporal dementia, Pick's disease and argyrophilic grain dementia. Among these diseases, amyotrophic lateral sclerosis and frontotemporal dementia have the most significant neurofibrillary pathology (Michaelis et al., 2002; Hardy, 2003; Roder, 2003). Furthermore, besides human, tau immunoreactivity and deposition-like structures are also found in rhesus monkeys (Garver et al., 1994; Hartig et al., 2000). NFTs can be detected by anti-tau antibody or silver staining. In AD, NFTs are found in the hippocampus, the entorhinal cortex, the association cortex and some other subcortical areas, such as the nucleus basalis of Meynert, the amygdala and the dorsal raphe (Arnold et al., 1991; Braak and Braak, 1994).

In vitro exposure of non-phosphorylated recombinant tau to high concentrations of sulfated glycosaminoglycans leads to the formation of paired helical filaments and single-strand filaments (Goedert et al., 1996). These results suggest that tau phosphorylation as well as the interaction of tau and glycosaminoglycans may play a role in abnormal filament formation in vivo. Phosphorylated tau has reduced ability to bind microtubules, which changes the stability of microtubules. In addition, phosphorylated tau may also affect intracellular transportation, cellular geometry and neuronal viability (Lassmann et al., 1995; Smale et al., 1995; Troncoso et al., 1996). 


\subsection{Synaptic and neuronal loss \\ 3.3.1 Synaptic loss}

In $\mathrm{AD}$, a significant synaptic loss ranging from $20 \%$ to $50 \%$ is reported. Biochemistry, electron microscopy and immunocytochemistry have shown a decrease in synaptic density, presynaptic terminals, synaptic vesicle and synaptic protein markers in AD brains compared with the normal aged controls (Terry et al., 1991; Geula, 1998; Larson et al., 1999; Yao et al., 1999; Ashe, 2000; Baloyannis et al., 2000; Terry, 2000; Masliah, 2001; Masliah et al., 2001b; Price et al., 2001; Scheff and Price, 2001; Scheff et al., 2001; Stephan et al., 2001; Callahan et al., 2002; Chan et al., 2002; Dodd, 2002). Although synaptic loss is remarkable in $\mathrm{AD}$, it is not specific to AD. Reduction in synaptic density is also found in Pick's disease, Huntington's disease, Parkinson's disease as well as in vascular dementia (Geula, 1998; Larson et al., 1999; Yao et al., 1999; Ashe, 2000; Baloyannis et al., 2000; Terry, 2000; Masliah, 2001; Masliah et al., 2001b; Price et al., 2001; Scheff and Price, 2001; Scheff et al., 2001; Stephan et al., 2001; Callahan et al., 2002; Chan et al., 2002; Dodd, 2002).

Since one of the most important physiological functions of synapses is to release and accept neurotransmitters, the changes of activity of these neurotransmitters in neurodegenerative diseases have also been intensively studied (Terry, 2000). In AD, most significant lesions happen in the cholinergic, adrenergic and serotoninergic systems (Davies and Maloney, 1976; Geula, 1998; Larson et al., 1999; Yao et al., 1999; Ashe, 2000; Baloyannis et al., 2000; Terry, 2000; Masliah, 2001; Masliah et al., 2001b; Price et al., 2001; Scheff and Price, 2001; Scheff et al., 2001; Stephan et al., 2001; Callahan et al., 2002; Chan et al., 2002; Dodd, 2002). Some other peptidergic neurotransmitters also decrease in AD, such as somatostatin, neuropeptide $\mathrm{Y}$ and substance $\mathrm{P}$ (Terry, 2000).

Synaptic loss might be one of the first events in AD development (Terry et al., 1991; Terry, 2000; Selkoe, 2002). Decrease in presynaptic terminals, synaptic vesicle and synaptic protein markers occur in very early stage of AD (Ashe, 2000; Terry, 2000; Masliah et al., 2001b; Price et al., 2001; Scheff et al., 2001; Callahan et al., 2002; Chan et al., 2002; Dodd, 2002). In the transgenic mice with FAD mutations, synaptophysin, marker for presynaptic protein, decreases before the appearance of $\mathrm{A} \beta$ deposits and formation of plaques (Hamos et al., 1989; Masliah et al., 1989; Selkoe, 2002). Most importantly, the decline of function of synaptic transmission occurs even before synaptic structural changes (Masliah, 2001; Scheff and Price, 2001; Chan et al., 2002; Selkoe, 2002). Long-term potentiation (LTP) is commonly accepted as a measurement for capacity of synaptic plasticity, which is the basis of learning, memory and complex information processing. The incidence and duration of LTP formation are used as an indication for formation and maintenance of working memory. Several lines of FAD mutant transgenic mice show a decline in the formation of LTP and synaptic excitation before the appearance of synaptic loss, plaques and other AD pathology (Geula, 1998; Ashe, 2000; Masliah, 2001; Masliah et al., 2001b; Scheff and Price, 2001; Callahan et al., 2002; Chan et al., 2002; Selkoe, 2002). In summary, synaptic loss seems to appear earlier than all other pathological markers and the functional loss of synapses may be responsible for the initiation of cognitive decline in $\mathrm{AD}$ patients.

\subsubsection{Neuronal loss}

Synaptic loss and degeneration induce neuronal dysfunction and cell body loss. Neuronal loss in the cerebral cortex and the hippocampus is a hallmark feature of AD. Some of $\mathrm{AD}$ 
patients at late stage of the disease can have a severe decrease in brain volume and weight due to either neuronal loss or atrophy (Smale et al., 1995; Cotman and Su, 1996; GomezIsla et al., 1996; Gomez-Isla et al., 1997; Li et al., 1997; Su et al., 1997; Gomez-Isla et al., 1999). Assumption-based and design-based unbiased stereological cell counting shows decreased density of neurons in the cerebral cortex, the entorhinal cortex, the association cortex, the basal nucleus of Meynert, the locus coeruleus and the dorsal raphe of AD brains (Bondareff et al., 1982; Lippa et al., 1992; Gomez-Isla et al., 1996; Gomez-Isla et al., 1997; Gomez-Isla et al., 1999; Colle et al., 2000). Profound neuronal loss is especially observed in the entorhinal cortex in the mild AD brains (Gomez-Isla et al., 1996; GomezIsla et al., 1997; Gomez-Isla et al., 1999). Besides AD, significant neuronal loss is also observed in the entorhinal cortex in very mild cognitive impairment patient brains (Gomez-Isla et al., 1996; Gomez-Isla et al., 1997; Gomez-Isla et al., 1999). These data suggest that neuronal loss may be one of the early events before formation of SPs and NFTs in AD development.

The loss of cholinergic neurons in AD is widely studied. The hippocampus and cortex receive major cholinergic input from the basal forebrain nuclei (Hohmann et al., 1987). Decrease of choline acetyltransferase activity and acetylcholine synthesis correlate well with the degree of cognitive impairment in AD patients (Mesulam, 1986; Hohmann et al., 1987; Pearson and Powell, 1987). Cholinergic neuronal lesion can be detected in the patients that have showed clinical memory loss symptoms for less than one year (Whitehouse et al., 1981; Whitehouse et al., 1982; Francis et al., 1993; Weinstock, 1997). However, markers for dopamine, $\gamma$-aminobutyric acid (GABA), or somatostatin are not altered (Whitehouse et al., 1981; Whitehouse et al., 1982; Francis et al., 1993). These results suggest that cholinergic neuronal loss is probably one of the early events in AD.

\subsection{Correlation of AD pathology to dementia levels}

Besides the main pathology discussed above, some other pathologies of AD include granulovacuolar degeneration, cerebral amyloid angiopathy, blood-brain barrier disorder, white matter lesions, neuropil thread and gliosis (Jellinger, 2002a; Jellinger, 2002b, c; Jellinger and Attems, 2003). Because of a lack of diagnostic markers for live AD patients, the definite diagnosis of $\mathrm{AD}$ depends on cognitive tests and a quantitative assessment of numbers of SPs and NFTs in the postmortem brain tissues. However, studies of the relationship of the major AD pathological markers with clinical dementia levels suggest that the best correlation with dementia is neither SPs nor NFTs. The extent of neuronal and synaptic loss correlates better with the severity of clinical disease than the neuropathological lesions, SPs and NFTs (De Kosky and Scheff, 1990; Terry et al., 1991), suggesting that neuronal loss has a closer and more direct relationship to clinical dementia.

\section{4. $A \beta$ and $A \beta$ hypothesis in $A D$}

\subsection{Production of $A \beta$}

\subsubsection{APP}

One of the most remarkable pathological features of AD is extracellular deposition of SPs containing A $\beta$ peptide aggregates derived from amyloid precursor protein (APP). APP, cloned in 1987 (Kang et al., 1987), is a type-1 transmembrane glycoprotein with ten isoforms generated by alternative mRNA splicing. APP is encoded by a single gene at human 
chromosome 21 containing 18 exons (Kang et al., 1987; Goate et al., 1991). APP has a signal peptide, a large extracellular $\mathrm{N}$ terminal domain and a small intracellular $\mathrm{C}$ terminal domain, a single transmembrane domain and an endocytosis signal at the $\mathrm{C}$ terminal (Golde et al., 1992; Haass et al., 1992a; Haass et al., 1992b; Haass et al., 1994; Lai et al., 1995) (Figure 1A). Among ten isoforms of APP ranging from 563 to 770 amino acids, the major ones are $\mathrm{APP}_{770}, \mathrm{APP}_{751}$ and $\mathrm{APP}_{695}$. Isoforms $\mathrm{APP}_{751}$ and $\mathrm{APP}_{770}$ are expressed in both peripheral neural and non-neural tissues and have a protease inhibitor domain in the extracellular regions (Kitaguchi et al., 1988; Ponte et al., 1988). Isoform $\mathrm{APP}_{695}$, which lacks the KPI domain, is expressed at high levels in the brain (Yamada et al., 1989; Kang and Muller-Hill, 1990; LeBlanc et al., 1991). Since the CNS neurons are mostly affected in AD, intensive efforts have been made to focus on the $\mathrm{APP}_{695}$ isoform (Sinha and Lieberburg, 1999).

Under physiological conditions, newly synthesized APP matures in the endoplasmic reticulum and the Golgi, acquiring $\mathrm{N}$ - and O-linked glycosylation and phosphorylation. The function of APP phosphorylation is not known yet. APP is located in the neuronal cell bodies as well as axons. Cellular APP is transported by the fast anterograde system (Koo et al., 1990; Sisodia et al., 1993), therefore, it is suggested that APP may play a role in neurite

(A)

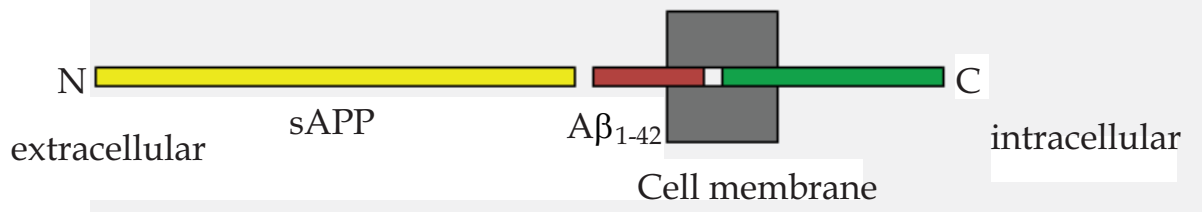

(B)

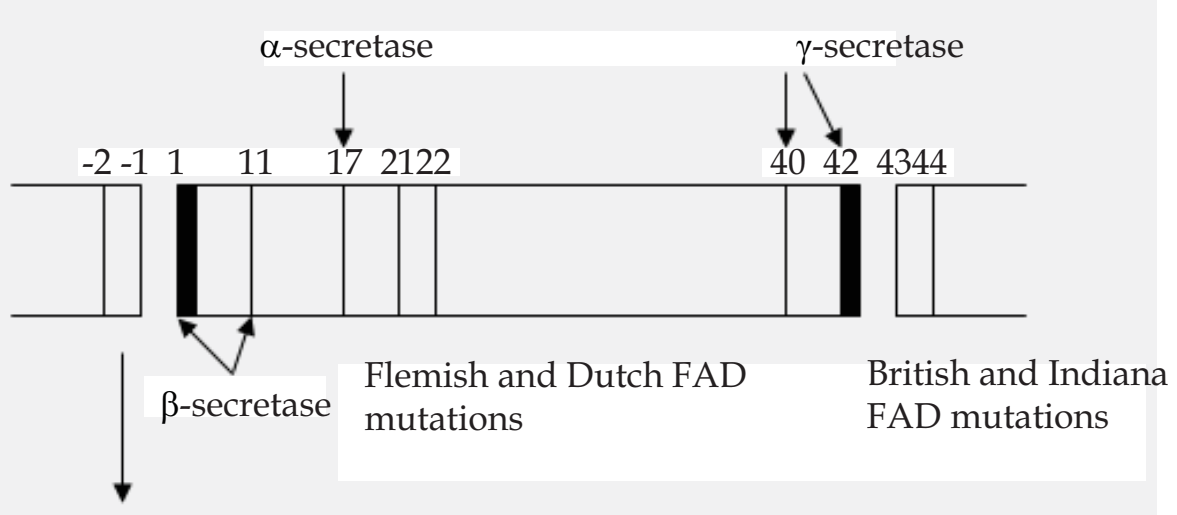

Swedish FAD mutations

$$
\mathrm{A} \beta_{1-42}
$$

Fig. 1. Schematic diagram of APP and its cleavage. (A) Full-length APP is located in the cell membrane. (B) APP can be cleaved at $\alpha-$, or $\beta$ - and $\gamma$-secretase sites. FAD mutations are often at cleavage sites 
outgrowth and extension, and probably in synaptic transmission and maintenance of axons (Yamaguchi et al., 1990; Yamaguchi et al., 1994). In addition, APP has been suggested to have neuroprotective function or neurotrophic roles (Mattson et al., 1993b). APP knockouts are fertile (Zheng et al., 1996). Neuroanatomical studies of APP knockout mouse brains show no significant differences relative to the wild-type control brains (Zheng et al., 1996). APP can be cleaved at the $C$ terminal by $\alpha$-secretase near the cell surface to generate a secreted fragment (Sinha and Lieberburg, 1999) (Figure 1B). The exact location of $\alpha-$ secretase activity is still unknown, although some data suggest that $\alpha$-cleavage occurs mainly at trans-Golgi or plasma membrane (Kuentzel et al., 1993). One possible explanation for the uncertainty about the localization of $\alpha$-secretase is that there may be more than one enzyme with the $\alpha$-secretase activity. The candidates for $\alpha$-secretase are two members of the family of disintegrin and metalloprotease ADAM: tumour necrosis factorconverting enzyme (TACE or ADAM-17) and ADAM-10. TACE can process pro-TNF, creating the extracellular TNF in a similar way to APP. The blockage or knockout of TACE can decrease the release of sAPP (Buxbaum et al., 1998). However, cells lacking TACE still retain part of $\alpha$-secretase activity (Buxbaum et al., 1998). In addition to TACE, overexpression of ADAM-10 increases $\alpha$-cleavage of APP (Lammich et al., 1999). A dominant negative form of ADAM-10 inhibits $\alpha$-secretase activity, but does not totally abolish sAPP production (Lammich et al., 1999). ADAM-10 is inactive in the Golgi, while becomes activated at the plasma membrane (Lammich et al., 1999). Therefore, TACE and ADAM-10 may both contribute to $\alpha$-cleavage.

In addition to $\alpha$-secretase pathway, APP can also be cleaved by putative $\beta$ - and $\gamma$-secretases to generate $A \beta$ fragments containing 39-43 amino acids (Figure 1B). The majority of $A \beta$ peptides is the 40 amino acid long $A \beta_{1-40}$, only $10 \%$ of the species are the 42 amino acid peptide $A \beta_{1-42}$. $\beta$-site APP cleaving enzyme (BACE or Asp2) has been suggested to be responsible for $\beta$-secretase activity. BACE is a member of pepsin family of aspartyl proteases (Vassar et al., 1999). BACE cleaves full-length APP at Asp1 (Vassar et al., 1999). The Swedish FAD mutation, which is known to enhance $\beta$-secretase cleavage, also promotes cleavage of APP at Asp1 by BACE (Vassar et al., 1999). BACE is co-localized with APP in many regions, especially in neurons. BACE also has a subcellular distribution similar to $\beta$-secretase (Vassar et al., 1999).

Recent studies suggest that $\gamma$-secretase may not be a single protein but rather mediated by a complex of a number of proteins. $\gamma$-secretase activity happens when APP is cleaved within the complex containing presenilin, APP binding proteins Nicastrin, Aph-1 and Pen-2 (Yu et al., 2000; Chen et al., 2001; Chung and Struhl, 2001; Satoh and Kuroda, 2001; Hu et al., 2002). There are two proposed $\beta$ - and $\gamma$-secretase pathways. One is called the endosomal/lysosomal pathway. Secreted APP is endocytosed and delivered to endosomes and lysosomes where $\beta$ - and $\gamma$-secretase cleavages occur. The other pathway suggests that $\mathrm{A} \beta$ generation occurs in the endoplasmic reticulum and Golgi-derived vesicles (Chyung et al., 1997; Sinha and Lieberburg, 1999). The $\gamma$-cleavage and the role of presenilins in this cleavage are discussed in details in the following section about presenilins.

Mutations in the APP gene identified 25 families of FAD worldwide (Chartier-Harlin et al., 1991a; Chartier-Harlin et al., 1991b) (Figure 1B). All these APP mutations are missense mutations. Double mutation Lys670Asn/Met671Leu ("Swedish" mutation), Ala693Gly ("Flemish" mutation), Glu693Gln ("Dutch" mutation) and Ile716Val (Czech et al., 2000) increase $\mathrm{A} \beta$ production, especially the generation of $\mathrm{A} \beta_{1-42}$. The "Dutch" mutation is a point 
mutation within the $A \beta$ peptide sequence and leads to a conformational change of $A \beta$, which increases the aggregation of $\mathrm{A} \beta$ peptides and forms fibrils (Levy et al., 1990; Wisniewski et al., 1997). The "Flemish" mutation is also located within A $\beta$ sequence and alters $\gamma$-secretase activity leading to increased production of $A \beta_{1-42}$ (Haass et al., 1994). The "Arctic" mutation Glu693Gly does not increase A $\beta$ production, but the amount of protofibrils of A $\beta$ increases (Nilsberth et al., 2001). Besides the APP mutations leading to obligate AD phenotype, other evidence that APP is associated with AD comes from DS patients. DS patients have 3 copies of chromosome 21 leading to overexpression of APP. Almost all DS patients develop AD in their 30-40's (reviewed by (Lott and Head, 2001)). Two "APP-like" genes APLP1 amd APLP2 have been localized to human chromosome 19 and suggested to be a strong candidate for late onset FAD (Wasco et al., 1992).

\subsubsection{Presenilin}

Besides the APP gene, FAD is also associated with mutations in the presenilin (PS) genes (Deng et al., 1996a; Busciglio et al., 1997; Hartmann et al., 1997; Price and Sisodia, 1998; Grace et al., 2002; Grace and Busciglio, 2003). PSs are transmembrane proteins with 8 transmembrane domains, located mainly in the endoplasmic reticulum, Golgi, endoplasmic reticulum-Golgi intermediate structures, and synaptic terminals as detected by electron microscopy (Cook et al., 1996; Takashima et al., 1996; Culvenor et al., 1997; Huynh et al., 1997; Lah et al., 1997; McGeer et al., 1998; Tanimukai et al., 1999; Culvenor et al., 2000; Siman et al., 2001). The PS1 gene is located on human chromosome 14 and the PS2 gene is on chromosome 1 (Sherrington et al., 1996). In humans, both PS1 and PS2 are encoded by 12 exons (Hutton et al., 1996). PSs are highly expressed in human brain, especially in neurons, and in most peripheral tissues (Deng et al., 1996b; Sherrington et al., 1996). There is a strong sequence homology between PS1 and PS2 (Sherrington et al., 1996). PSs are highly conserved from Drosophila to human (Hong and Koo, 1997; Berezovska et al., 1999). While no PS homologues are found in yeast, a PS homologue is found in Arabidopsis thaliana, (Czech et al., 2000). PSs are not glycosylated, sulfated or acylated (De Strooper et al., 1997).

The physiological functions of PSs are widely studied. PS knockout studies show that PS1 is important for axial skeleton development. PS1 knockouts have severe defects in their bone and skeleton systems. Interestingly, the phenotype of PS1 knockouts is very similar to the Notch-1 knockouts, which indicates that PSs may play an important role in the Notch signaling pathway (Wong et al., 1997). In addition, the interaction between PSs and Notch is suggested by co-immunoprecipitation of endogenous Notch and PSs in cultured Drosophila cells (Ray et al., 1999). Notch is processed in the secretory pathway and cleaved the Golgi. The two truncated subunits of Notch form a protein complex in the plasma membrane and act as a receptor. When Notch ligand binds to this receptor, one of the two subunits gets cleaved at the extracellular site near the membrane. Then, the intracellular fragment of the cleaved subunit is released into the cytosol. This fragment then translocates into the nucleus and acts as a part of a transcriptional factor complex. This complex can regulate, at the transcriptional level, Notch target genes (De Strooper et al., 1999). The studies of the PS knockouts and Notch function suggest that PSs may be the proteases responsible for Notch cleavage and regulating the trafficking of cleaved Notch to the cytosol (De Strooper et al., 1999). A similar scenario has been proposed for APP processing by PS (De Strooper et al., 1999). 
The link between PS1 or PS2 with AD was found through genetic studies of FAD cases. PS1 mutation families have early onset of $\mathrm{AD}$ at around 50 years old, whereas PS2 mutation families develop AD symptoms between 40-80 years old (Rogaev et al., 1995). The majority of these PS mutations are missense mutations leading to amino acid change in the protein sequence. If an individual carries a PS mutation, the probability of developing early onset $\mathrm{AD}$ is higher than 95\% (Annaert et al., 1999). PS mutations are likely to be a "gain of toxic function" resulting in the abnormal APP processing, probably as part of the " $\gamma$-secretase" complex that generates $A \beta$ fragments. PS mutations increase $A \beta$, especially $A \beta_{1-42}$ production (Busciglio et al., 1997; Hartmann et al., 1997). PSs can interact with APP directly. This is supported by the fact that APP and PSs can be co-immunoprecipitated in transfected cells and interact in a yeast two-hybrid system (Waragai et al., 1997; Weidemann et al., 1997; Xia et al., 1998). Whether PSs act directly as the $\gamma$-secretase and how PSs cleave APP inside its transmembrane domain are still not clear yet. One model proposes that PSs regulate APP intracellular trafficking and lead APP to the subcellular compartments, most possibly, the endoplasmic reticulum, where $\gamma$-secretase cleavage happens (Davis et al., 1998). Two aspartic acid sites (D257, D385) on PS1 are likely to be critical for $\gamma$-secretase cleavage because mutations of these two sites significantly decrease $\gamma$-secretase cleavage (Tandon and Fraser, 2002). Since $\gamma$-secretase cleavage happens inside of the transmembrane domain of APP, it is suggested that the $\gamma$-secretase complex (PSs, Nicastrin, Aph-1 and Pen-2) form a pore structure on the membrane. APP is then located and stabilized in the middle of the pore by Nicastrin or Pen-2 (Yu et al., 2000; Chen et al., 2001; Chung and Struhl, 2001; Satoh and Kuroda, 2001; Hu et al., 2002).

\section{2 $A \beta$ involvement and $A \beta$ hypothesis in $A D$}

To date, the cause of AD is still not clear. Major pathological features of AD are intracellular NFTs composed of hyperphosphorylated tau, extracellular SPs containing A $\beta$ peptides, and massive synaptic and neuronal loss. Accordingly, there are tau, A $\beta$ and synaptic-neuronal loss hypotheses for the cause of AD. The amyloid hypothesis, on the other hand, emphasizes that increased $A \beta$ production or failure of $A \beta$ clearance induces gradual $A \beta$ accumulation through life, resulting in the formation of amyloid plaques, which induces inflammatory responses and in turn induces synaptic damage, tangles, and then neuronal loss (Podlisny et al., 1987; Hardy and Higgins, 1992). The evidence supporting the amyloid hypothesis comes from studies showing that most of FAD mutations increase $\mathrm{A} \beta$ production (Czech et al., 2000). As mentioned in the $A \beta$ section above, both extracellular and intracellular $A \beta$ are toxic to cells. In addition, co-expression of mutant APP and mutant tau increase NFTs, but not SPs, suggesting that $A \beta$ production and accumulation may be upstream to tau to induce tangle formation (Lewis et al., 2001). In addition, the evidence from Down's syndrome patients suggests that SP formation precedes NFT (Mann et al., 1989; Lemere et al., 1996). Furthermore, in a FAD mutation carrier who died from other disease unrelated to AD in middle life, autopsy showed that the load of amyloid deposition and SPs but not NFT (Smith et al., 2001), suggesting that SP formation may happen before NFT formation. However, tau mutants can cause fontotemporal dementia where lots of tangles, but not amyloid deposits, are found in the brain, suggesting that NFT and SP formation may be independent (Hutton et al., 1998; Poorkaj et al., 1998; Spillantini and Goedert, 1998). Therefore, from this point of view, it seems that $A \beta$ accumulation is either preceding or independent of NFT formation. The $A \beta$ deposition in the neural parenchyma occurs early in 
plaque formation, and this peptide species is the major component in the mature plaque (Price and Sisodia, 1998). A $\beta$ production increases in the cells expressing FAD mutations (Price and Sisodia, 1998). These A $\beta$ deposits may also act as a backbone for the subsequent deposits of other proteins, such as $\alpha_{1}$-antichymotrypsin, apolipoprotein $\mathrm{E}$ (apoE) and J (Rogers et al., 1988).

The aggregations of $A \beta$ are toxic to neurons and are thought to contribute to neuronal loss in AD development (Yankner, 1996). Since extracellular A $\beta$ deposition is a major pathological hallmark of $\mathrm{AD}$, considerable attention has been devoted to the $\mathrm{A} \beta$ cytotoxicity hypothesis, which argues that the extracellular $\mathrm{A} \beta$ (eA $\beta$ ), especially eA $\beta_{1-42}$, induces neuronal death, therefore, is one of the primary causes of AD (Yankner et al., 1990; Roses, 1996; Scheuner et al., 1996; Sinha and Lieberburg, 1999; De Strooper and Annaert, 2000; Wang et al., 2001). The eA $\beta$ toxicity hypothesis is supported by the fact that fibrillar eA $\beta$ is toxic to various systems, including cell lines and primary cells in cultures (Yankner et al., 1990; Kowall et al., 1991; Pike et al., 1991; Busciglio et al., 1992, Busciglio, 1993 \#189; Behl et al., 1994; Hoyer, 1994; Lorenzo and Yankner, 1994b; Price et al., 1995; Lorenzo and Yankner, 1996; Roher et al., 1996). Furthermore, levels of $A \beta$, especially $A \beta_{1-42}$, increase in the AD brains and in the serum or fibroblasts from the AD patients (reviewed by (Price and Sisodia, 1998)). Although the mechanism of eA $\beta$ cytotoxicity is still not fully understood, proposed eA $\beta$ toxicity mechanisms include: increasing vulnerability of cells to a secondary insult (Mattson et al., 1993a; Behl et al., 1994), changes in calcium influx (Ho et al., 2001), increasing oxidative stress (Behl et al., 1994), activation of inflammation and microglia (Eikelenboom et al., 2002; Gasic-Milenkovic et al., 2003), changes in tau phosphorylation (Ghribi et al., 2003), induction of apoptosis (Colurso et al., 2003; Hashimoto et al., 2003; Monsonego et al., 2003), induction of lysosomal protease activity and damaging membrane (Bahr and Bendiske, 2002; Bendiske and Bahr, 2003). Also, eA $\beta$ can interacts with receptors on the cell membrane, such as the p75 neurotrophin receptors, APP, receptors for advanced glycation endproducts (RAGE) (Loo et al., 1993; Yan et al., 1997; Yarr et al., 1997; Yaar et al., 2002).

Like many other amyloidogenous proteins, $A \beta$ undergoes oligomerization and fibrillation under physiological situations (Zerovnik et al., 2011). The mechanisms of amyloid fibril formation have been suggested as "templating and nucleation models", "linear colloid-like assembly of spherical oligomers", and "domain-swapping" (Zerovnik et al., 2011). Recent studies have demonstrated that soluble $\mathrm{A} \beta$ oligomers have toxic role (Haass and Selkoe, 2007; Walsh and Selkoe, 2007). A $\beta$ oligomers have been shown to induce cognitive defects when transferred into wild type murine brains (Podlisny et al., 1998; Walsh et al., 2000; Walsh et al., 2002b; Walsh et al., 2002a; Walsh et al., 2005b; Walsh et al., 2005a; Lesne et al., 2006; Townsend et al., 2006; Shankar et al., 2009). Soluble oligomers form trimers and tetramers that disrupt normal synaptic function (Salminen et al., 2008), precede synapse loss (Salminen et al., 2008). A $\beta$ oligomers induce inhibited LTP and enhanced long-term depression (Malchiodi-Albedi et al., 2011). The mechanisms of A $\beta$ oligomer toxicity have been suggested to be associated with calcium dysregulation (Malchiodi-Albedi et al., 2011), inflammation activation (Salminen et al., 2008), potassium efflux activation (Salminen et al., 2008) and interaction with membrane lipid rafts (Simons and Gerl, 2010) and microglia (Malchiodi-Albedi et al., 2011).

Several lines of evidence suggest that eA $\beta$ may not be the sole contributor to AD pathology. First, in $\mathrm{AD}$ patients, the severity of $\mathrm{A} \beta$ deposition correlates poorly with clinical dementia 
levels (Barcikowska et al., 1992). Second, in some AD animal models, A $\beta$ accumulates and forms SPs in the absence of the other two AD pathological features, neuronal loss and NFTs (Price and Sisodia, 1998; Masliah et al., 2001a). Third, eA $\beta$ toxicity generally requires nonphysiological micro molar levels of $A \beta$ in the culture medium. Moreover, some groups have reported that eA $\beta$ is not toxic even at high micro molar concentration in rat PC12, human IMR32 cells and in monkey cerebral cortex (Busciglio et al., 1992; Podlisny et al., 1993; Gschwind and Huber, 1995). One of the best models to study human age-related diseases, human primary cultured neurons, is resistent to $10 \mu \mathrm{M}$ of eA $\beta$ (Mattson et al., 1992; Paradis et al., 1996). A secondary insult, such as serum deprivation, is required for eA $\beta$ to induce cell death in human neurons (Paradis et al., 1996). Fourth, transgenic mice carrying FAD APPV717F mutation show neuronal and synaptic loss before A $\beta$ accumulation (Hsia et al., 1999). In addition, human neuronal cell death induced by serum deprivation increases eA $\beta$ production, suggesting that eA $\beta$ generation is a consequence instead of a cause of neuronal cell loss (LeBlanc et al., 1999). Interestingly, in human primary neurons, p75 neurotrophin receptors play a protective role against eA $\beta$ toxicity. Blocking $\mathrm{p} 75$ by anti-sense constructs or antibody significantly promotes eA $\beta$ toxicity (Zhang et al., 2003). In addition, in some AD animal models, $A \beta$ accumulates to form SPs in the absence of two other AD pathological features, neuronal loss and NFT (Price and Sisodia, 1998; Masliah et al., 2001a). Furthermore, the number of SPs does not correlate with the degree of cognitive impairment. In some older people without dementia, lots of SPs are found in their brains.

Recently, findings implicating intracellular $\mathrm{A} \beta$ (iA $\beta$ ) accumulation and toxicity in $\mathrm{AD}$ are attracting more and more attention. The accumulation of iA $\beta$ has been observed. First, iA $\beta_{1-}$ 42 significantly accumulates in the pyramidal neurons of the hippocampus and the entorhinal cortex in mild cognitive impairment and AD patient brains (Chui et al., 1999; Gouras et al., 2000; D'Andrea et al., 2001; D'Andrea et al., 2002; Nagele et al., 2002; Tabira et al., 2002; Takahashi et al., 2002; Wang et al., 2002). Similar accumulations of $A \beta_{1-42}$ also occur in neurons of DS (Busciglio et al., 2002; Takahashi et al., 2002) and muscle cells of IBM individuals (Askanas et al., 1992; Sugarman et al., 2002), two degenerative disorders other than $\mathrm{AD}$ associated with amyloid deposition. Second, this iA $\beta_{1-42}$ accumulation appears earlier than amyloid plaque formation (Gouras et al., 2000; D'Andrea et al., 2001; Tabira et al., 2002; Takahashi et al., 2002; Wang et al., 2002). Third, in the cell culture system, accumulation of iA $\beta_{1-42}$ was reported (Yang et al., 1998; Greenfield et al., 1999). Fourth, in the transgenic animal models, iA $\beta$ accumulation precedes NFT formation in APP/PS1 double mutant mice (Wirths et al., 2001). In the APP mutant mice where synaptic loss happens before the presence of eA $\beta$, iA $\beta$ was also reported (Li et al., 1996; Masliah et al., 1996; Hsia et al., 1999). Furthermore, using neuronal specific promoter NF-L, $A \beta_{1-42}$ expressed intracellularly in the neurons of transgenic mice induces dramatic cell loss (LaFerla et al., 1995). Microinjection of intracellular $A \beta_{1-42}$ into neurons induces dramatic cell death mediated through the activation of p53, Bax and caspase-6 (Zhang et al., 2002; Li et al., 2007). Intracellular $A \beta_{1-42}$ also causes electrophysiological property changes in primary human neurons (Hou et al., 2009). Androgen (Zhang et al., 2004), estrogen (Zhang et al., 2004), galanin (Cui et al., 2010) can protect against such toxicity.

Under physiological conditions, A $\beta$ peptides are normally generated in the endoplasmic reticulum, Golgi or endosomal-lysosomal pathway, and secreted to the extracellular environment (Martin et al., 1995; Chyung et al., 1997; Tienari et al., 1997; Lee et al., 1998; 
Greenfield et al., 1999). There are three possible pathways that may generate iA $\beta$. One is that $\mathrm{A} \beta$ goes through endoplasmic reticulum-associated degradation (ERAD) pathway. When $\mathrm{A} \beta$ is made in the endoplasmic reticulum, the insoluble $\mathrm{A} \beta$ could be recognized as a misfolded protein and then reverse translocate from the endoplasmic reticulum to the cytosol. The misfolded proteins are then ubiquitinated and sent to proteasome for degradation (Werner et al., 1996; Greenfield et al., 1999; Friedlander et al., 2000; Ng et al., 2000; VanSlyke and Musil, 2002). It is possible that aging decreases proteasome activity (Merker et al., 2001), which leads to insufficient degradation and clearance of $A \beta$. The second possible way to generate $\mathrm{iA} \beta$ is that $\mathrm{A} \beta$ fragments can be located in the endosome/lysosome transported from the trans-Golgi or through endocytosis. It has been suggested that $A \beta$ can increase the membrane permeability of lysosome (Yang et al., 1998). Therefore, the $A \beta$ within the endosome/lysosome can break the lysosome membrane and leak out of the vesicles. The third possible way is that there could be leakage happening along any of the secretory pathway. It is even possible that secreted A $\beta$ passively diffuses into the cytosol through the plasma membrane or is actively uptaken by certain receptors on the plasma membrane.

\section{Potential $A D$ therapies based on $A \beta$ hypothesis}

\subsection{Decreasing $A \beta$ production}

$\mathrm{A} \beta$ is generated from cleavage of APP by $\beta$ - and $\gamma$-secretase (Vassar and Citron, 2000). $\beta$-secretase, a membrane-bound aspartic protease, is also called BACE, is most abundant in the brain (Vassar and Citron, 2000). BACE knockout mice apparently lack phenotype, which suggests that maybe inhibition of BACE in adult mice does not have side effect, and can be an excellent drug target for the cure of AD. However, there is a homologue of BACE, BACE2 (Vassar and Citron, 2000), which compensates the function of BACE. So, drugs which inhibit BACE, not BACE2, make sense in decreasing $A \beta$ production. $\gamma$-secretase releases $A \beta$ from APP. However, compared to $\beta$-secretase, $\gamma$-secretase is less understood. It is known that transmembrane proteins PS1 and PS2 (Strooper and Annaert, 2001), and nicastrin (Kopan and Goate, 2002) are required for the activity of $\gamma$-secretase. $\gamma$-secretase is involved in the cleavage of other integral membrane proteins including Notch (Strooper and Annaert, 2001), CD44 receptor (Okamoto et al., 2001). The mice die early in embryogenesis if $\gamma$-secretase is totally inhibited. Therefore, reasonable treatment with $\gamma$-secretase is partially inhibit $\gamma$-secretase, or inhibits the $\gamma$-secretase specifically cleaves APP to yield A $\beta$ (Strooper and Annaert, 2001) (Figure 2).

Non-steroidal anti-inflammatory drugs (NSAIDs) are also candidates for AD drug target, because inflammation in $\mathrm{AD}$ is an important inducement for neuronal loss and it causes microglia activation, cytokines and complement components in the vicinity of the plaques (McGeer and McGeer, 1999; Akiyama et al., 2000). Clinic treatment of NSAIDs could specifically slow down the progression of AD (in t' Veld et al., 2001). NSAIDs target cyclooxygenases (COX) 1 and 2, while COX-2 inhibitors have little effects (McGeer, 2000). Recently, the study shows that the protective role of NSAIDs may be independent of their role in inflammation (Weggen et al., 2001). The production of A $\beta$ in NSAIDs treated cells is apparently inhibited (De Strooper and Konig, 2001). But we still don't know how the NSAIDs specifically reduce the production of $A \beta$ (Figure 2). 

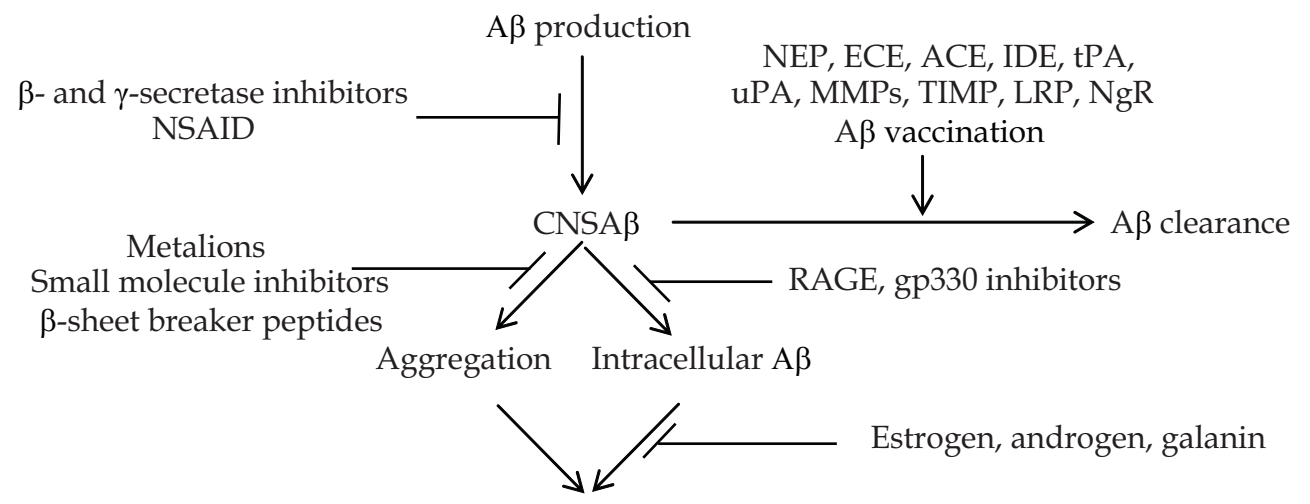

Toxicity<smiles>C[Al]</smiles>

Neuronal and synaptic loss<smiles>C=IC</smiles>

Cognition impairment

Fig. 2. Schematic diagram of $A \beta$ production, clearance, aggregation and toxicity

\subsection{Increasing $A \beta$ clearance \\ 5.2.1 Neprilysin (NEP)}

Neprilysin, also called neutral endopeptidease (NEP), enkephalinase, CD10, or common acute lymphoblastic leukemia antigen (CALLA), is a zinc metallopeptidase with a zincbinding motif (Turner and Tanzawa, 1997). NEP is a type II integral membrane protein with a short amino-terminal and localized at the cell membrane. NEP binds to many extracellular proteins or peptides, such as enkephalins, substance $\mathrm{P}$, atrial natriuretic peptide, somatostatin, endothelin and insulin B chain. The physiological role of NEP is not fully understood yet. Studies suggest its possible implications in the regulation of natriuretic and vasodilator peptides in the kidney, the modulation of inflammatory response by neutrophils and the inactivation of mitogenic signaling in various cells (Turner et al., 2001). NEP is highly localized at the synapses (Schwartz et al., 1980) and colocalized with SP and A $\beta$ (Sato et al., 1991). NEP can hydrolyze synthetic $A \beta_{1-40}$ in vitro (Howell et al., 1995) and synthetic $A \beta_{1-42}$ injected into rat hippocampus in vivo (Iwata et al., 2000). Mice with disrupted NEP gene show decreased ability of degrading exogenous $A \beta_{1-42}$ and endogenous $A \beta_{40 / 42}$ (Iwata et al., 2001). Endogenous $A \beta$ accumulates in the hippocampus of this animal model which correlates with the severity of AD pathology (Iwata et al., 2001). Also, in human AD brain samples, NEP mRNA levels are low in the vulnerable areas, such as the hippocampus and the temporal cortex (Yasojima et al., 2001) (Figure 2).

Besides NEP, two other proteases related to NEP were also found to degrade A $\beta$. Endothelinconverting enzyme (ECE) hydrolyzes endogenous and synthetic $A \beta$ in neuroblastoma cells and transfected $\mathrm{CHO}$ cells (Eckman et al., 2001). ECE can also degrade $A \beta_{1-40}$ and $A \beta_{1-42}$ into $A \beta_{1-16}, A \beta_{1-17}$ and $A \beta_{1-19}$ in vitro (Eckman et al., 2001). An intronic polymorphism of angiotensin 
converting enzyme (ACE) is found to be a possible susceptibility genetic factor (Narain et al., 2000). Purified ACE from human seminal fluid is able to degrade $A \beta_{1-40}$ and reduce $A \beta$ fibrillogenesis and cytotoxicity (Hu et al., 2001) (Figure 2).

\subsubsection{Insulin-degrading enzyme (IDE)}

Insulin-degrading enzyme (IDE), also called insulysin and insulinase, is a neutral thiol metalloendopeptidase with an inverted zinc-binding site. IDE can hydrolyze multiple peptides, including amylin, and the APP intracellular domain in addition to A $\beta$ (Duckworth et al., 1998; Selkoe, 2001). Purified nondenatured IDE migrates from 300kDa to 110kDa after denaturation, which indicates that native IDE exists as a mixture of dimers and tetramers (Authier et al., 1996; Duckworth et al., 1998). IDE is significantly activated in neutral pH and dimmers formation (Mirsky et al., 1949; Kurochkin, 2001; Song et al., 2003). IDE was found to be located to the 125 I-labeled synthetic $A \beta$ in cytosol fractions from rat brain and liver (Kurochkin and Goto, 1994). Purified IDE effectively degrades A $\beta$ in vivo and in vitro (McDermott and Gibson, 1997; Perez et al., 2000), proved by the transgenic APP mouse as well (Farris et al., 2003; Farris et al., 2004) (Figure 2).

\subsubsection{Plasmin, tissue plasminogen activator (tPA), urokinase-type plaminogen activator (UPA), matrix metalloproteinases and endosomal/lysosomal proteases}

Plasmin, a serin protease, can degrade many extracellular matrix components (Werb, 1997). Plasmin, tissue plasminogen activator (tPA), and urokinase-type plaminogen activator (uPA) all belong to the plasimin system (Henkin et al., 1991). Plasmin, the active serine protease, is generated from tPA expressed in neurons and uPA expressed in neurons and microglial cells by cleavage of plasminogen (Madani et al., 2003). It is reported that plasmin significantly decreases the neurotoxicity of $A \beta$ aggregation by degrading $A \beta$, which has been proved by cell culture (Ledesma et al., 2000; Ledesma et al., 2003) (Figure 2).

Matrix metalloproteinases (MMPs) is a large family which can degrade and remodel extracellular matrix. MMPs have common propeptide and N-terminal catalytic domains (Yong et al., 1998). MMPs are activated by a proteolytic processing, regulated by tissue inhibitors of matrix metalloproteinases (TIMP), which can bind to the active or the inactive form of the MMPs (Brew et al., 2000). TIMP is found to co-localize with neuritic plaques and neurofibrillary tangles. Incubation of MMP-9 and synthetic A $\beta 1-40$ can produce several products of degradation (Backstrom et al., 1996). The other MMPs can also performe this kind of cleavage (Figure 2).

Endosomal and lysosomal proteases can protect neuron cells by internalization of extracellular $\mathrm{A} \beta$ though a number of receptors such as lipoprotein receptor-related protein (LRP), receptor for advanced glycation and products (RAGE), gp330/megalin and P-glycoproein as indicated in the following text. In AD models, alterations occur to lysosomal, including the accumulation of lysosomes and lysosomal hydrolases, next to A $\beta$ deposits (Ii et al., 1993; Cataldo et al., 1994). Cathepsin D protein level and activity are increased in aging brain, and the CSF of AD patients (Cataldo et al., 1995; Hoffman et al., 1998). It is reported that cathepsin D gene is associated with sporadic AD (Papassotiropoulos et al., 1999) (Figure 2).

\subsubsection{A $\beta$ vaccination}

The active and passive immunizations have been examined in in vitro models and proven effective against $\mathrm{A} \beta$ pathology, cellular alterations and cognitive impairment in AD animal 
models (Schenk et al., 1999; Bard et al., 2000; Janus et al., 2000; Morgan et al., 2000; DeMattos et al., 2001; Lemere et al., 2001; DeMattos et al., 2002a; DeMattos et al., 2002b; Dodart et al., 2002; Matsuoka et al., 2003; Lemere et al., 2004; Hartman et al., 2005; Selkoe, 2007; Vasilevko et al., 2007; Yamada et al., 2009). After vaccination of $A \beta$, a transgenic mouse over expressing a mutant form of human APP is protected against amyloid plaque formation (Schenk et al., 1999). This vaccination not only protects A $\beta$ aggregation, but also clears the amyloids in the brain of adult mice (Weiner et al., 2000). For vaccination, the antibody is directly injected by intraperitoneal immunization (Bard et al., 2000; DeMattos et al., 2001). The antibodies go across the blood-brain barrier, and probably trigger microglia to phagocytose $A \beta$. There is an alternative working mechanism: the antibodies make $A \beta$ trapped in the plasma, which in turn reduce the extracellular concentration of A $\beta$ (Janus et al., 2000; Morgan et al., 2000). Although the concentration of A $\beta$ decreased after the vaccination, the cognitive function in these models is not apparently affected, which may due to the metabolism of $A \beta$; another problem for the vaccination is the clinical signs of inflammation in the CNS of several patients. According to $\mathrm{A} \beta$ vaccination, lower toxicity and higher immunogenicity (Nicolau et al., 2002) should be mainly considered (Figure 2).

\subsubsection{Receptor mediated $A \beta$ clearance}

LRP and RAGE are both multi-ligand receptors binding to various ligands (Tanzi et al., 2004), trafficking A $\beta$ across the blood-brain barrier (BBB) (Deane et al., 2004; Zlokovic, 2008). LRP1, a member of the low-density lipoprotein (LDL) receptor family, binds to various structurally unrelated ligands, apoE, APP, lactoferrin and A $\beta$ included (Deane and Zlokovic, 2007). LRP1 antagonists (Shibata et al., 2000) or low expression level of LRP1 (Van Uden et al., 2002) apparently increase A $\beta$ load (Deane et al., 2008; Marques et al., 2009). $\beta$-secretase cleaves the extracellular domain of LRP to produce soluble LRP, which can binds to free A $\beta$ in the plasma in order to reduce the concentration of extracellular $A \beta$ (Sagare et al., 2007). RAGE is a member of immunoglobulin super family, mediating the reentry of $A \beta$ in to the brain through BBB. RAGE can bind to soluble $A \beta$ at a nanomolar concentration (Deane et al., 2003), and this kind of interaction is indicated in injuries, imflammatory, and AD brains (Yan et al., 1996; Stern et al., 2002; Deane et al., 2003). In addition, Nogo-66 receptor (NgR) (Park and Strittmatter, 2007; Tang and Liou, 2007), gp330/megalin and P-glycoproein (Zlokovic, 1996; Lam et al., 2001) can also contribute to A $\beta$ trafficking, with their respective role in transforming $\mathrm{A} \beta$ through $\mathrm{BBB}$ unknown (Figure 2).

Besides the clearance pathways mentioned above, one of the AD risk factor apoE $\varepsilon 4$ allele can alter $A \beta$ clearance (Castellano et al., 2011). In a mouse model of $A \beta$-amyloidosis expressing human apoE isoforms (PDAPP/TRE), the concentration and clearance of soluble $\mathrm{A} \beta$ in the brain interstitial fluid is reported to depend on the isoform type of apoE, especially in aged PDAPP/TRE mice (Castellano et al., 2011).

\subsection{Preventing $A \beta$ aggregation formation}

Mental ions like $\mathrm{Cu}^{2+}$ and $\mathrm{Zn}^{2+}$ are found to reduce the aggregation and toxicity of $\mathrm{A} \beta$ (Atwood et al., 1998). Clioruinol, an antibiotic and $\mathrm{Cu}^{2+} / \mathrm{Zn}^{2+}$ clelator that crosses the blood-brain barrier, can significantly decrease brain A $\beta$ depositon in APP-transgenic mice after 9-week treatment (Cherny et al., 2001). In the progression of $A \beta$ aggregation formation, a number of small molecules can interfere with the $\mathrm{A} \beta$ fibril in vivo or in vitro, such as rifampicin (Tomiyama et al., 1996), Congo red (Lorenzo and Yankner, 1994a), benzofuran 
(Howlett et al., 1999), and Nicotine (Salomon et al., 1996) etc., with different principles as follows. Rifampicin prevents $A \beta$-induced oxidative damage as a free radical scavenger, because the nahpthohydroquinone and naphthoquinone structure protect the neuron cells (Tomiyama et al., 1996). Congo reds may inhibit the aggregation of $A \beta$ through two sulfonate groups at a certain distance, which indicates the specific interaction of the negatively charged sulfonate moieties with A $\beta$ (Pollack et al., 1995; Klunk et al., 1998). Just like a number of tetracyclic and carbazole-type compounds, benzofuran inhibits A $\beta$ fibril formation, as a result of the inhibitory properties of these compounds (Howlett et al., 1999). Nicotine can prevent the conformational transition from $\alpha$-helix to $\beta$-sheet (Salomon et al., 1996), and attenuate the neurotoxicity of $\mathrm{A} \beta$ through the nicotine receptor (Zamani et al., 1997). Nicotine also enhances the biosynthesis and secretion of transthyretin, which could bind to $A \beta$ peptide to inhibit the formation of amyloid deposition (Tsuzuki et al., 2000). " $\beta$-sheet breaker peptides", another way to prevent $A \beta$ aggregation formation, are two peptides with sequences complementary to $A \beta$, with additional proline residues, which inhibit the formation of $\beta$-sheet structures (Soto et al., 1996; Soto et al., 1998). The sequences of the " $\beta$ sheet breaker peptides" are RDLPFFDVPID and LPFFD. According to the usage of peptides in the treatment of disease in the central nervous system, rapid proteolytic degradation in the plasma and cerebrospinal fluid, and low permeability across the bloodbrain barrier should be taken into account (Poduslo et al., 1999) (Figure 2).

\section{List of abbreviations}

$\mathrm{A} \beta$ : amyloid $\beta$; ACE: angiotensin converting enzyme; AD: Alzheimer's disease; apoE: apolipoprotein E; APP: amyloid precursor protein; BACE: $\beta$-site APP cleaving enzyme; BBB: blood-brain barrier; CALLA: common acute lymphoblastic leukemia antigen; COX: cyclooxygenases; DS: Down's syndrome; eA $\beta$ : extracellular A $\beta$; ECE: endothelin-converting enzyme; ERAD: endoplasmic reticulum-associated degradation; FAD: familial AD; GABA: $\gamma$-aminobutyric acid; iA $\beta$ : intracellular A $\beta$; IDE: insulin-degrading enzyme; LRP: lipoprotein receptor-related protein; LTP: long-term potentiation; MMP: matrix metalloproteinases; NEP: neutral endopeptidease; NFT: neurofibrillary tangles; NgR: Nogo-66 receptor; NSAID: non-steroidal anti-inflammatory drug; PS: presenilin; RAGE: receptor for advanced glycation end products; SP: senile plaques; TACE: tumour necrosis factor-converting enzyme; TIMP: tissue inhibitors of matrix metalloproteinases; tPA: tissue plasminogen activator; uPA: urokinase-type plaminogen activator

\section{Conclusions}

Amyloid hypothesis stating that $\mathrm{A} \beta$ is the primary cause of $\mathrm{AD}$ has been proposed and examined in AD research field. However, many controversial issues still exist and further studies are needed to increase our understanding about AD development and progression. The therapeutics, which stem from the knowledge of basic research, may become another effective way to evaluate the theory itself.

\section{Disclosure statement}

All authors declare no actual or potential conflicts of interest including any financial, personal or other relationships with other people or organizations within three years of beginning the work submitted that could inappropriately influence (bias) their work. 


\section{Acknowledgements}

This work was supported by the National Program of Basic Research sponsored by the Ministry of Science and Technology of China (2009CB941301), Peking University President Research Grant, Ministry of Education Recruiting Research Grant and Roche Research Grant.

\section{References}

Akiyama H et al. (2000) Inflammation and Alzheimer's disease. Neurobiol Aging 21:383-421. Alorainy I (2000) Senile scleral plaques: CT. Neuroradiology 42:145-148.

Annaert WG, Levesque L, Craessaerts K, Dierinck I, Snellings G, Westaway D, GeorgeHyslop PS, Cordell B, Fraser P, De Strooper B (1999) Presenilin 1 controls gammasecretase processing of amyloid precursor protein in pre-golgi compartments of hippocampal neurons. J Cell Biol 147:277-294.

Arnold SE, Hyman BT, Flory J, Damasio AR, van Hoesen GW (1991) The topographical and neuroanatomical distribution of neurofibrillary tangles and neuritic plaques in the cerebral cortex of patients with Alzheimer's disease. Cereb Cortex 1:103-116.

Ashe KH (2000) Synaptic structure and function in transgenic APP mice. Ann N Y Acad Sci 924:39-41.

Askanas V, Engel WK, Alvarez RB (1992) Light and electron microscopic localization of beta-amyloid protein in muscle biopsies of patients with inclusion-body myositis. Am J Pathol 141:31-36.

Atwood A, Choi J, Levin HL (1998) The application of a homologous recombination assay revealed amino acid residues in an LTR-retrotransposon that were critical for integration. J Virol 72:1324-1333.

Authier F, Posner BI, Bergeron JJ (1996) Insulin-degrading enzyme. Clin Invest Med 19:149160.

Backstrom JR, Lim GP, Cullen MJ, Tokes ZA (1996) Matrix metalloproteinase-9 (MMP-9) is synthesized in neurons of the human hippocampus and is capable of degrading the amyloid-beta peptide (1-40). J Neurosci 16:7910-7919.

Bahr BA, Bendiske J (2002) The neuropathogenic contributions of lysosomal dysfunction. J Neurochem 83:481-489.

Baloyannis SJ, Manolidis SL, Manolidis LS (2000) Synaptic alterations in the vestibulocerebellar system in Alzheimer's disease--a Golgi and electron microscope study. Acta Otolaryngol 120:247-250.

Barcikowska M, Kujawa M, Wisniewski H (1992) beta-Amyloid deposits within the cerebellum of persons older than 80 years of age. Neuropatol Pol 30:285-293.

Bard F et al. (2000) Peripherally administered antibodies against amyloid beta-peptide enter the central nervous system and reduce pathology in a mouse model of Alzheimer disease. Nat Med 6:916-919.

Behl C, Davis J, Lesley R, Schubert D (1994) Hydrogen peroxide mediates amyloid b protein toxicity. Cell 77:817-827.

Bendiske J, Bahr BA (2003) Lysosomal activation is a compensatory response against protein accumulation and associated synaptopathogenesis--an approach for slowing Alzheimer disease? J Neuropathol Exp Neurol 62:451-463.

Berezovska O, Frosch M, McLean P, Knowles R, Koo E, Kang D, Shen J, Lu FM, Lux SE, Tonegawa S, Hyman BT (1999) The Alzheimer-related gene presenilin 1 facilitates notch 1 in primary mammalian neurons. Brain Res Mol Brain Res 69:273-280. 
Boller F, Verny M, Hugonot-Diener L, Saxton J (2002) Clinical features and assessment of severe dementia. A review. Eur J Neurol 9:125-136.

Bondareff W, Mountjoy CQ, Roth M (1982) Loss of neurons of origin of the adrenergic projection to cerebral cortex (nucleus locus ceruleus) in senile dementia. Neurology 32:164-168.

Braak H, Braak E (1994) Pathology of Alzheimer's disease. In: Neurodegenerative Disease., pp 585-613. Philadelphia: Saunders.

Braak H, Braak E, Ohm T, Bohl J (1989) Alzheimer's disease: mismatch between amyloid plaques and neuritic plaques. Neurosci Lett 103:24-28.

Brew K, Dinakarpandian D, Nagase H (2000) Tissue inhibitors of metalloproteinases: evolution, structure and function. Biochim Biophys Acta 1477:267-283.

Busciglio J, Lorenzo A, Yankner BA (1992) Methodological variables in the assessment of beta amyloid neurotoxicity. Neurobiol Aging 13:609-612.

Busciglio J, Pelsman A, Wong C, Pigino G, Yuan M, Mori H, Yankner BA (2002) Altered metabolism of the amyloid beta precursor protein is associated with mitochondrial dysfunction in Down's syndrome. Neuron 33:677-688.

Busciglio J, Hartmann H, Lorenzo A, Wong C, Baumann K, Sommer B, Staufenbiel M, Yankner BA (1997) Neuronal localization of presenilin-1 and association with amyloid plaques and neurofibrillary tangles in Alzheimer's disease. J Neurosci 17:5101-5107.

Buxbaum JD, Liu KN, Luo Y, Slack JL, Stocking KL, Peschon JJ, Johnson RS, Castner BJ, Cerretti DP, Black RA (1998) Evidence that tumor necrosis factor alpha converting enzyme is involved in regulated alpha-secretase cleavage of the Alzheimer amyloid protein precursor. J Biol Chem 273:27765-27767.

Callahan LM, Vaules WA, Coleman PD (2002) Progressive reduction of synaptophysin message in single neurons in Alzheimer disease. J Neuropathol Exp Neurol 61:384-395.

Castellano JM, Kim J, Stewart FR, Jiang H, Demattos RB, Patterson BW, Fagan AM, Morris JC, Mawuenyega KG, Cruchaga C, Goate AM, Bales KR, Paul SM, Bateman RJ, Holtzman DM (2011) Human apoE Isoforms Differentially Regulate Brain Amyloid-\{beta\} Peptide Clearance. Sci Transl Med 3:89ra57.

Cataldo AM, Hamilton DJ, Nixon RA (1994) Lysosomal abnormalities in degenerating neurons link neuronal compromise to senile plaque development in Alzheimer disease. Brain Res 640:68-80.

Cataldo AM, Barnett JL, Berman SA, Li J, Quarless S, Bursztajn S, Lippa C, Nixon RA (1995) Gene expression and cellular content of cathepsin D in Alzheimer's disease brain: evidence for early up-regulation of the endosomal-lysosomal system. Neuron 14:671-680.

Chan SL, Furukawa K, Mattson MP (2002) Presenilins and APP in neuritic and synaptic plasticity: implications for the pathogenesis of Alzheimer's disease. Neuromolecular Med 2:167-196.

Chartier-Harlin MC, Crawford F, Hamandi K, Mullan M, Goate A, Hardy J, Backhovens H, Martin JJ, Broeckhoven CV (1991a) Screening for the beta-amyloid precursor protein mutation (APP717: Val----Ile) in extended pedigrees with early onset Alzheimer's disease. Neurosci Lett 129:134-135.

Chartier-Harlin MC, Crawford F, Houlden H, Warren A, Hughes D, Fidani L, Goate A, Rossor M, Roques P, Hardy J, et al. (1991b) Early-onset Alzheimer's disease caused by mutations at codon 717 of the beta-amyloid precursor protein gene. Nature 353:844-846. 
Chen F, Yu G, Arawaka S, Nishimura M, Kawarai T, Yu H, Tandon A, Supala A, Song YQ, Rogaeva E, Milman P, Sato C, Yu C, Janus C, Lee J, Song L, Zhang L, Fraser PE, St George-Hyslop PH (2001) Nicastrin binds to membrane-tethered Notch. Nat Cell Biol 3:751-754.

Cherny RA, Atwood CS, Xilinas ME, Gray DN, Jones WD, McLean CA, Barnham KJ, Volitakis I, Fraser FW, Kim Y, Huang X, Goldstein LE, Moir RD, Lim JT, Beyreuther K, Zheng H, Tanzi RE, Masters CL, Bush AI (2001) Treatment with a copper-zinc chelator markedly and rapidly inhibits beta-amyloid accumulation in Alzheimer's disease transgenic mice. Neuron 30:665-676.

Chui DH, Tanahashi H, Ozawa K, Ikeda S, Checler F, Ueda O, Suzuki H, Araki W, Inoue H, Shirotani K, Takahashi K, Gallyas F, Tabira T (1999) Transgenic mice with Alzheimer presenilin 1 mutations show accelerated neurodegeneration without amyloid plaque formation. Nat Med 5:560-564.

Chung HM, Struhl G (2001) Nicastrin is required for Presenilin-mediated transmembrane cleavage in Drosophila. Nat Cell Biol 3:1129-1132.

Chyung AS, Greenberg BD, Cook DG, Doms RW, Lee VM (1997) Novel beta-secretase cleavage of beta-amyloid precursor protein in the endoplasmic reticulum/intermediate compartment of NT2N cells. J Cell Biol 138:671-680.

Colle MA, Duyckaerts C, Laquerriere A, Pradier L, Czech C, Checler F, Hauw JJ (2000) Laminar specific loss of isocortical presenilin 1 immunoreactivity in Alzheimer's disease. Correlations with the amyloid load and the density of tau-positive neurofibrillary tangles. Neuropathol Appl Neurobiol 26:117-123.

Colurso GJ, Nilson JE, Vervoort LG (2003) Quantitative assessment of DNA fragmentation and beta-amyloid deposition in insular cortex and midfrontal gyrus from patients with Alzheimer's disease. Life Sci 73:1795-1803.

Cook DG, Sung JC, Golde TE, Felsenstein KM, Wojczyk BS, Tanzi RE, Trojanowski JQ, Lee VM, Doms RW (1996) Expression and analysis of presenilin 1 in a human neuronal system: localization in cell bodies and dendrites. Proc Natl Acad Sci U S A 93:92239228.

Cork LC, Powers RE, Selkoe DJ, Davies P, Geyer JJ, Price DL (1988) Neurofibrillary tangles and senile plaques in aged bears. J Neuropathol Exp Neurol 47:629-641.

Cotman CW, Su JH (1996) Mechanism of neuronal death in Alzheimer's disease. Brain Pathol 6:493-506.

Cui J, Chen Q, Yue X, Jiang X, Gao GF, Yu LC, Zhang Y (2010) Galanin protects against intracellular amyloid toxicity in human primary neurons. J Alzheimers Dis 19:529544.

Culvenor JG, Maher F, Evin G, Malchiodi-Albedi F, Cappai R, Underwood JR, Davis JB, Karran EH, Roberts GW, Beyreuther K, Masters CL (1997) Alzheimer's diseaseassociated presenilin 1 in neuronal cells: evidence for localization to the endoplasmic reticulum-Golgi intermediate compartment. J Neurosci Res 49:719-731.

Culvenor JG, Evin G, Cooney MA, Wardan H, Sharples RA, Maher F, Reed G, Diehlmann A, Weidemann A, Beyreuther K, Masters CL (2000) Presenilin 2 expression in neuronal cells: induction during differentiation of embryonic carcinoma cells. Exp Cell Res 255:192-206.

Cummings BJ, Satou T, Head E, Milgram NW, Cole GM, Savage MJ, Podlisny MB, Selkoe DJ, Siman R, Greenberg BD, Cotman CW (1996) Diffuse plaques contain C-terminal A beta 42 and not A beta 40: evidence from cats and dogs. Neurobiol Aging 17:653659 . 
Czech C, Tremp G, Pradier L (2000) Presenilins and Alzheimer's disease: biological functions and pathogenic mechanisms. Prog Neurobiol 60:363-384.

D'Andrea MR, Nagele RG, Wang HY, Peterson PA, Lee DH (2001) Evidence that neurones accumulating amyloid can undergo lysis to form amyloid plaques in Alzheimer's disease. Histopathology 38:120-134.

D'Andrea MR, Nagele RG, Gumula NA, Reiser PA, Polkovitch DA, Hertzog BM, AndradeGordon P (2002) Lipofuscin and Abeta42 exhibit distinct distribution patterns in normal and Alzheimer's disease brains. Neurosci Lett 323:45-49.

Davies P, Maloney AJ (1976) Selective loss of central cholinergic neurons in Alzheimer's disease. Lancet 2:1403.

Davis JA, Naruse S, Chen H, Eckman C, Younkin S, Price DL, Borchelt DR, Sisodia SS, Wong PC (1998) An Alzheimer's disease-linked PS1 variant rescues the developmental abnormalities of PS1-deficient embryos. Neuron 20:603-609.

De Kosky ST, Scheff SW (1990) Synapse loss in frontal lobe biopsies in Alzheimer's disease: Correlation with cognitive severity. Ann Neurol 27:457-464.

De Strooper B, Annaert W (2000) Proteolytic processing and cell biological functions of the amyloid precursor protein. J Cell Sci 113:1857-1870.

De Strooper B, Konig G (2001) An inflammatory drug prospect. Nature 414:159-160.

De Strooper B, Beullens M, Contreras B, Levesque L, Craessaerts K, Cordell B, Moechars D, Bollen M, Fraser P, George-Hyslop PS, Van Leuven F (1997) Phosphorylation, subcellular localization, and membrane orientation of the Alzheimer's diseaseassociated presenilins. J Biol Chem 272:3590-3598.

De Strooper B, Annaert W, Cupers P, Saftig P, Craessaerts K, Mumm JS, Schroeter EH, Schrijvers V, Wolfe MS, Ray WJ, Goate A, Kopan R (1999) A presenilin-1-dependent gamma-secretase-like protease mediates release of Notch intracellular domain. Nature 398:518-522.

Deane R, Zlokovic BV (2007) Role of the blood-brain barrier in the pathogenesis of Alzheimer's disease. Curr Alzheimer Res 4:191-197.

Deane R, Sagare A, Zlokovic BV (2008) The role of the cell surface LRP and soluble LRP in blood-brain barrier Abeta clearance in Alzheimer's disease. Curr Pharm Des 14:1601-1605.

Deane R, Wu Z, Sagare A, Davis J, Du Yan S, Hamm K, Xu F, Parisi M, LaRue B, Hu HW, Spijkers P, Guo H, Song X, Lenting PJ, Van Nostrand WE, Zlokovic BV (2004) LRP/amyloid beta-peptide interaction mediates differential brain efflux of Abeta isoforms. Neuron 43:333-344.

Deane R et al. (2003) RAGE mediates amyloid-beta peptide transport across the blood-brain barrier and accumulation in brain. Nat Med 9:907-913.

Defigueiredo RJ, Cummings BJ, Mundkur PY, Cotman CW (1995) Color image analysis in neuroanatomical research: application to senile plaque subtype quantification in Alzheimer's disease. Neurobiol Aging 16:211-223.

DeMattos RB, Bales KR, Cummins DJ, Paul SM, Holtzman DM (2002a) Brain to plasma amyloid-beta efflux: a measure of brain amyloid burden in a mouse model of Alzheimer's disease. Science 295:2264-2267.

DeMattos RB, Bales KR, Cummins DJ, Dodart JC, Paul SM, Holtzman DM (2001) Peripheral anti-A beta antibody alters CNS and plasma A beta clearance and decreases brain A beta burden in a mouse model of Alzheimer's disease. Proc Natl Acad Sci U S A 98:8850-8855. 
DeMattos RB, Bales KR, Parsadanian M, O'Dell MA, Foss EM, Paul SM, Holtzman DM (2002b) Plaque-associated disruption of CSF and plasma amyloid-beta (Abeta) equilibrium in a mouse model of Alzheimer's disease. J Neurochem 81:229-236.

Deng G, Pike CJ, Cotman CW (1996a) Alzheimer-associated presenilin-2 confers increased sensitivity to apoptosis in PC12 cells. FEBS Lett 397:50-54.

Deng G, Su JH, Cotman CW (1996b) Gene expression of Alzheimer-associated presenilin-2 in the frontal cortex of Alzheimer and aged control brain. FEBS Lett 394:17-20.

Dodart JC, Bales KR, Gannon KS, Greene SJ, DeMattos RB, Mathis C, DeLong CA, Wu S, Wu X, Holtzman DM, Paul SM (2002) Immunization reverses memory deficits without reducing brain Abeta burden in Alzheimer's disease model. Nat Neurosci 5:452-457.

Dodd PR (2002) Excited to death: different ways to lose your neurones. Biogerontology 3:5156.

Duckworth WC, Bennett RG, Hamel FG (1998) Insulin degradation: progress and potential. Endocr Rev 19:608-624.

Eckman EA, Reed DK, Eckman CB (2001) Degradation of the Alzheimer's amyloid beta peptide by endothelin-converting enzyme. J Biol Chem 276:24540-24548.

Eikelenboom P, Bate C, Van Gool WA, Hoozemans JJ, Rozemuller JM, Veerhuis R, Williams A (2002) Neuroinflammation in Alzheimer's disease and prion disease. Glia 40:232239.

Farris W, Mansourian S, Leissring MA, Eckman EA, Bertram L, Eckman CB, Tanzi RE, Selkoe DJ (2004) Partial loss-of-function mutations in insulin-degrading enzyme that induce diabetes also impair degradation of amyloid beta-protein. Am J Pathol 164:1425-1434.

Farris W, Mansourian S, Chang Y, Lindsley L, Eckman EA, Frosch MP, Eckman CB, Tanzi RE, Selkoe DJ, Guenette S (2003) Insulin-degrading enzyme regulates the levels of insulin, amyloid beta-protein, and the beta-amyloid precursor protein intracellular domain in vivo. Proc Natl Acad Sci U S A 100:4162-4167.

Francis PT, Webster MT, Chessell IP, Holmes C, Stratmann GC, Procter AW, Cross AJ, Green AR, Bowen DM (1993) Neurotransmitters and second messengers in aging and Alzheimer's disease. Ann N Y Acad Sci 695:19-26.

Friedlander R, Jarosch E, Urban J, Volkwein C, Sommer T (2000) A regulatory link between ER-associated protein degradation and the unfolded-protein response. Nat Cell Biol 2:379-384.

Garver TD, Harris KA, Lehman RA, Lee VM, Trojanowski JQ, Billingsley ML (1994) Tau phosphorylation in human, primate, and rat brain: evidence that a pool of tau is highly phosphorylated in vivo and is rapidly dephosphorylated in vitro. J Neurochem 63:2279-2287.

Gasic-Milenkovic J, Dukic-Stefanovic S, Deuther-Conrad W, Gartner U, Munch G (2003) beta-Amyloid peptide potentiates inflammatory responses induced by lipopolysaccharide, interferon -gamma and 'advanced glycation endproducts' in a murine microglia cell line. Eur J Neurosci 17:813-821.

Gearing M, Tigges J, Mori H, Mirra SS (1997) beta-Amyloid (A beta) deposition in the brains of aged orangutans. Neurobiol Aging 18:139-146.

Gearing M, Schneider JA, Robbins RS, Hollister RD, Mori H, Games D, Hyman BT, Mirra SS (1995) Regional variation in the distribution of apolipoprotein E and A beta in Alzheimer's disease. J Neuropathol Exp Neurol 54:833-841.

Geula C (1998) Abnormalities of neural circuitry in Alzheimer's disease: hippocampus and cortical cholinergic innervation. Neurology 51:S18-29; discussion S65-17. 
Ghribi O, Herman MM, Savory J (2003) Lithium inhibits Abeta-induced stress in endoplasmic reticulum of rabbit hippocampus but does not prevent oxidative damage and tau phosphorylation. J Neurosci Res 71:853-862.

Glenner GG, Wong CW (1984) Alzheimer's disease: initial report of the purification and characterization of a novel cerebrovascular amyloid protein. biochem Biophys Res Comm 120:885-890.

Goate A, Chartier-Harlin MC, Mullan M, Brown J, Crawford F, Fidani L, Giuffra L, Haynes A, Irving N, James L, et al. (1991) Segregation of a missense mutation in the amyloid precursor protein gene with familial Alzheimer's disease. Nature 349:704-706.

Goedert M, Jakes R, Spillantini MG, Hasegawa M, Smith MJ, Crowther RA (1996) Assembly of microtubule-associated protein tau into Alzheimer-like filaments induced by sulphated glycosaminoglycans. Nature 383:550-553.

Gold M (2002) Tau therapeutics for Alzheimer's disease: the promise and the challenges. J Mol Neurosci 19:331-334.

Golde TE, Estus S, Younkin LH, Selkoe DJ, Younkin SG (1992) Processing of the amyloid protein precursor to potentially amyloidogenic derivatives. Science 255:728-730.

Gomez-Isla T, Price JL, McKeel DW, Jr., Morris JC, Growdon JH, Hyman BT (1996) Profound loss of layer II entorhinal cortex neurons occurs in very mild Alzheimer's disease. J Neurosci 16:4491-4500.

Gomez-Isla T, Growdon WB, McNamara M, Newell K, Gomez-Tortosa E, Hedley-Whyte ET, Hyman BT (1999) Clinicopathologic correlates in temporal cortex in dementia with Lewy bodies. Neurology 53:2003-2009.

Gomez-Isla T, Hollister R, West H, Mui S, Growdon JH, Petersen RC, Parisi JE, Hyman BT (1997) Neuronal loss correlates with but exceeds neurofibrillary tangles in Alzheimer's disease. Ann Neurol 41:17-24.

Gouras GK, Tsai J, Naslund J, Vincent B, Edgar M, Checler F, Greenfield JP, Haroutunian V, Buxbaum JD, Xu H, Greengard P, Relkin NR (2000) Intraneuronal Abeta42 accumulation in human brain. Am J Pathol 156:15-20.

Grace EA, Busciglio J (2003) Aberrant activation of focal adhesion proteins mediates fibrillar amyloid beta-induced neuronal dystrophy. J Neurosci 23:493-502.

Grace EA, Rabiner CA, Busciglio J (2002) Characterization of neuronal dystrophy induced by fibrillar amyloid beta: implications for Alzheimer's disease. Neuroscience 114:265-273.

Greenfield JP, Tsai J, Gouras GK, Hai B, Thinakaran G, Checler F, Sisodia SS, Greengard P, $\mathrm{Xu} \mathrm{H}$ (1999) Endoplasmic reticulum and trans-Golgi network generate distinct populations of Alzheimer beta-amyloid peptides. Proc Natl Acad Sci U S A 96:742747.

Gschwind M, Huber G (1995) Apoptotic cell death induced by beta-amyloid 1-42 peptide is cell type dependent. J Neurochem 65:292-300.

Haass C, Selkoe DJ (2007) Soluble protein oligomers in neurodegeneration: lessons from the Alzheimer's amyloid beta-peptide. Nat Rev Mol Cell Biol 8:101-112.

Haass C, Hung AY, Selkoe DJ, Teplow DB (1994) Mutations associated with a locus for familial Alzheimer's disease result in alternative processing of amyloid beta-protein precursor. J Biol Chem 269:17741-17748.

Haass C, Koo EH, Mellon A, Hung AY, Selkoe DJ (1992a) Targeting of cell-surface betaamyloid precursor protein to lysosomes: alternative processing into amyloidbearing fragments. Nature 357:500-503. 
Haass C, Schlossmacher MG, Hung AY, Vigo-Pelfrey C, Mellon A, Ostaszewski BL, Lieberburg I, Koo EH, Schenk D, Teplow DB, et al. (1992b) Amyloid beta-peptide is produced by cultured cells during normal metabolism. Nature 359:322-325.

Hamos JE, DeGennaro LJ, Drachman DA (1989) Synaptic loss in Alzheimer's disease and other dementias. Neurology 39:355-361.

Hardy J (2003) The Relationship between Amyloid and Tau. J Mol Neurosci 20:203-206.

Hardy JA, Higgins GA (1992) Alzheimer's disease: the amyloid cascade hypothesis. Science 256:184-185.

Hartig W, Klein C, Brauer K, Schuppel KF, Arendt T, Bruckner G, Bigl V (2000) Abnormally phosphorylated protein tau in the cortex of aged individuals of various mammalian orders. Acta Neuropathol (Berl) 100:305-312.

Hartman RE, Izumi Y, Bales KR, Paul SM, Wozniak DF, Holtzman DM (2005) Treatment with an amyloid-beta antibody ameliorates plaque load, learning deficits, and hippocampal long-term potentiation in a mouse model of Alzheimer's disease. J Neurosci 25:6213-6220.

Hartmann H, Busciglio J, Baumann KH, Staufenbiel M, Yankner BA (1997) Developmental regulation of presenilin-1 processing in the brain suggests a role in neuronal differentiation. J Biol Chem 272:14505-14508.

Hashimoto Y, Niikura T, Chiba T, Tsukamoto E, Kadowaki H, Nishitoh H, Yamagishi Y, Ishizaka M, Yamada M, Nawa M, Terashita K, Aiso S, Ichijo H, Nishimoto I (2003) The Cytoplasmic Domain of Alzheimer's Amyloid-\{beta\} Protein Precursor Causes Sustained Apoptosis Signal-Regulating Kinase 1/c-Jun NH2-Terminal KinaseMediated Neurotoxic Signal via Dimerization. J Pharmacol Exp Ther 306:889-902.

Henkin J, Marcotte P, Yang HC (1991) The plasminogen-plasmin system. Prog Cardiovasc Dis 34:135-164.

Ho R, Ortiz D, Shea TB (2001) Amyloid-beta promotes calcium influx and neurodegeneration via stimulation of $\mathrm{L}$ voltage-sensitive calcium channels rather than NMDA channels in cultured neurons. J Alzheimers Dis 3:479-483.

Hoffman KB, Bi X, Pham JT, Lynch G (1998) Beta-amyloid increases cathepsin D levels in hippocampus. Neurosci Lett 250:75-78.

Hohmann GF, Wenk GL, Lowenstein P, Brown ME, Coyle JT (1987) Age-related recurrence of basal forebrain lesion-induced cholinergic deficits. Neurosci Lett 82:253-259.

Hong CS, Koo EH (1997) Isolation and characterization of Drosophila presenilin homolog. Neuroreport 8:665-668.

Hou JF, Cui J, Yu LC, Zhang Y (2009) Intracellular amyloid induces impairments on electrophysiological properties of cultured human neurons. Neurosci Lett 462:294299.

Howell S, Nalbantoglu J, Crine P (1995) Neutral endopeptidase can hydrolyze betaamyloid(1-40) but shows no effect on beta-amyloid precursor protein metabolism. Peptides 16:647-652.

Howlett DR, Perry AE, Godfrey F, Swatton JE, Jennings KH, Spitzfaden C, Wadsworth H, Wood SJ, Markwell RE (1999) Inhibition of fibril formation in beta-amyloid peptide by a novel series of benzofurans. Biochem J 340 ( Pt 1):283-289.

Hoyer S (1994) Neurodegeneration, Alzheimer's disease, and beta-amyloid toxicity. Life Sci 55:1977-1983.

Hsia AY, Masliah E, McConlogue L, Yu GQ, Tatsuno G, Hu K, Kholodenko D, Malenka RC, Nicoll RA, Mucke L (1999) Plaque-independent disruption of neural circuits in Alzheimer's disease mouse models. Proc Natl Acad Sci U S A 96:3228-3233. 
Hu J, Igarashi A, Kamata M, Nakagawa H (2001) Angiotensin-converting enzyme degrades Alzheimer amyloid beta-peptide (A beta ); retards A beta aggregation, deposition, fibril formation; and inhibits cytotoxicity. J Biol Chem 276:47863-47868.

$\mathrm{Hu}$ Y, Ye Y, Fortini ME (2002) Nicastrin is required for gamma-secretase cleavage of the Drosophila Notch receptor. Dev Cell 2:69-78.

Hutton $\mathrm{M}$ et al. (1996) Complete analysis of the presenilin 1 gene in early onset Alzheimer's disease. Neuroreport 7:801-805.

Hutton M et al. (1998) Association of missense and 5'-splice-site mutations in tau with the inherited dementia FTDP-17. Nature 393:702-705.

Huynh DP, Vinters HV, Ho DH, Ho VV, Pulst SM (1997) Neuronal expression and intracellular localization of presenilins in normal and Alzheimer disease brains. J Neuropathol Exp Neurol 56:1009-1017.

Ii K, Ito H, Kominami E, Hirano A (1993) Abnormal distribution of cathepsin proteinases and endogenous inhibitors (cystatins) in the hippocampus of patients with Alzheimer's disease, parkinsonism-dementia complex on Guam, and senile dementia and in the aged. Virchows Arch A Pathol Anat Histopathol 423:185-194.

in $t^{\prime}$ Veld BA, Ruitenberg A, Hofman A, Launer LJ, van Duijn CM, Stijnen T, Breteler MM, Stricker BH (2001) Nonsteroidal antiinflammatory drugs and the risk of Alzheimer's disease. N Engl J Med 345:1515-1521.

Iwata N, Tsubuki S, Takaki Y, Shirotani K, Lu B, Gerard NP, Gerard C, Hama E, Lee HJ, Saido TC (2001) Metabolic regulation of brain Abeta by neprilysin. Science 292:1550-1552.

Iwata N, Tsubuki S, Takaki Y, Watanabe K, Sekiguchi M, Hosoki E, Kawashima-Morishima M, Lee HJ, Hama E, Sekine-Aizawa Y, Saido TC (2000) Identification of the major Abeta1-42-degrading catabolic pathway in brain parenchyma: suppression leads to biochemical and pathological deposition. Nat Med 6:143-150.

Janus C, Pearson J, McLaurin J, Mathews PM, Jiang Y, Schmidt SD, Chishti MA, Horne P, Heslin D, French J, Mount HT, Nixon RA, Mercken M, Bergeron C, Fraser PE, St George-Hyslop P, Westaway D (2000) A beta peptide immunization reduces behavioural impairment and plaques in a model of Alzheimer's disease. Nature 408:979-982.

Jellinger K (2002a) Prevalence of Alzheimer's disease in very elderly people: a prospective neuropathological study. Neurology 58:671-672; author reply 671-672.

Jellinger KA (2002b) Vascular-ischemic dementia: an update. J Neural Transm Suppl:1-23.

Jellinger KA (2002c) Alzheimer disease and cerebrovascular pathology: an update. J Neural Transm 109:813-836.

Jellinger KA, Attems J (2003) Incidence of cerebrovascular lesions in Alzheimer's disease: a postmortem study. Acta Neuropathol (Berl) 105:14-17.

Jucker M, Walker LC, Kuo H, Tian M, Ingram DK (1994) Age-related fibrillar deposits in brains of C57BL/ 6 mice. A review of localization, staining characteristics, and strain specificity. Mol Neurobiol 9:125-133.

Kang J, Muller-Hill B (1990) Differential splicing of Alzheimer's disease amyloid A4 precursor RNA in rat tissue: PreA4695 mRNA is predominantly produced in rat and human brain. BBRC 166:1192-1200.

Kang J, Lemaire HG, Unterbeck A, Salbaum JM, Masters CL, Grzeschik KH, Multhaup G, Beyreuther K, Muller-Hill B (1987) The precursor of Alzheimer's disease amyloid A4 protein resembles a cell-surface receptor. Nature 325:733-736. 
Kitaguchi N, Takahashi Y, Tokushima Y, Shiojiri S, Ito H (1988) Novel precursor of Alzheimer's disease amyloid protein shows protease inhibitory activity. Nature 331:530-532.

Klunk WE, Debnath ML, Koros AM, Pettegrew JW (1998) Chrysamine-G, a lipophilic analogue of Congo red, inhibits A beta-induced toxicity in PC12 cells. Life Sci 63:1807-1814.

Koo EH, Sisodia SS, Archer DR, Martin LJ, Weidemann A, Beyreuther K, Fischer P, Masters CL, Price DL (1990) Precursor of amyloid protein in Alzheimer disease undergoes fast anterograde axonal transport. Proc Natl Acad USA 87:1561-1565.

Kopan R, Goate A (2002) Aph-2/Nicastrin: an essential component of gamma-secretase and regulator of Notch signaling and Presenilin localization. Neuron 33:321-324.

Kowall NW, Beal MF, Busciglio J, Duffy LK, Yankner BA (1991) An in vivo model for the neurodegenerative effects of beta amyloid and protection by substance P. Proc Natl Acad Sci U S A 88:7247-7251.

Kuentzel SL, Ali SM, Altman RA, Greenberg BD, Raub TJ (1993) The Alzheimer betaamyloid protein precursor/protease nexin-II is cleaved by secretase in a trans-Golgi secretory compartment in human neuroglioma cells. Biochem J 295:367-378.

Kurochkin IV (2001) Insulin-degrading enzyme: embarking on amyloid destruction. Trends Biochem Sci 26:421-425.

Kurochkin IV, Goto S (1994) Alzheimer's beta-amyloid peptide specifically interacts with and is degraded by insulin degrading enzyme. FEBS Lett 345:33-37.

LaFerla FM, Tinkle BT, Bieberich CJ, Haudenschild CC, Jay G (1995) The Alzheimer's A beta peptide induces neurodegeneration and apoptotic cell death in transgenic mice. Nat Genet 9:21-30.

Lah JJ, Heilman CJ, Nash NR, Rees HD, Yi H, Counts SE, Levey AI (1997) Light and electron microscopic localization of presenilin-1 in primate brain. J Neurosci 17:1971-1980.

Lai A, Sisodia SS, Trowbridge IS (1995) Characterization of sorting signals in the betaamyloid precursor protein cytoplasmic domain. J Biol Chem 270:3565-3573.

Lam FC, Liu R, Lu P, Shapiro AB, Renoir JM, Sharom FJ, Reiner PB (2001) beta-Amyloid efflux mediated by p-glycoprotein. J Neurochem 76:1121-1128.

Lammich S, Kojro E, Postina R, Gilbert S, Pfeiffer R, Jasionowski M, Haass C, Fahrenholz F (1999) Constitutive and regulated alpha-secretase cleavage of Alzheimer's amyloid precursor protein by a disintegrin metalloprotease. Proc Natl Acad Sci U S A 96:3922-3927.

Larson J, Lynch G, Games D, Seubert P (1999) Alterations in synaptic transmission and longterm potentiation in hippocampal slices from young and aged PDAPP mice. Brain Res 840:23-35.

Lassmann H, Bancher C, Breitschopf H, Wegiel J, Bobinski M (1995) Cell death in Alzheimer's disease evaluated by DNA fragmentation in situ. Acta Neuropathol 89:35-41.

LeBlanc A, Liu H, Goodyer C, Bergeron C, Hammond J (1999) Caspase-6 role in apoptosis of human neurons, amyloidogenesis, and Alzheimer's disease. J Biol Chem 274:2342623436.

LeBlanc AC, Chen HY, Autilio-Gambetti L, Gambetti P (1991) Differential APP gene expression in rat cerebral cortex, meninges, and primary astroglial, microglial and neuronal cultures. FEBS Lett 292:171-178.

Ledesma MD, Da Silva JS, Crassaerts K, Delacourte A, De Strooper B, Dotti CG (2000) Brain plasmin enhances APP alpha-cleavage and Abeta degradation and is reduced in Alzheimer's disease brains. EMBO Rep 1:530-535. 
Ledesma MD, Abad-Rodriguez J, Galvan C, Biondi E, Navarro P, Delacourte A, Dingwall C, Dotti CG (2003) Raft disorganization leads to reduced plasmin activity in Alzheimer's disease brains. EMBO Rep 4:1190-1196.

Lee SJ, Liyanage U, Bickel PE, Xia W, Lansbury PT, Jr., Kosik KS (1998) A detergentinsoluble membrane compartment contains A beta in vivo. Nat Med 4:730-734.

Lee VMY, Balin BJ, Otvos LJ, Trojanowski JQ (1991) A68: a major subunit of paired helical filaments and derivatized forms of normal tau. Science 251:675-678.

Lemere CA, Maron R, Selkoe DJ, Weiner HL (2001) Nasal vaccination with beta-amyloid peptide for the treatment of Alzheimer's disease. DNA Cell Biol 20:705-711.

Lemere CA, Beierschmitt A, Iglesias M, Spooner ET, Bloom JK, Leverone JF, Zheng JB, Seabrook TJ, Louard D, Li D, Selkoe DJ, Palmour RM, Ervin FR (2004) Alzheimer's disease abeta vaccine reduces central nervous system abeta levels in a non-human primate, the Caribbean vervet. Am J Pathol 165:283-297.

Lemere CA, Lopera F, Kosik KS, Lendon CL, Ossa J, Saido TC, Yamaguchi H, Ruiz A, Martinez A, Madrigal L, Hincapie L, Arango JC, Anthony DC, Koo EH, Goate AM, Selkoe DJ (1996) The E280A presenilin 1 Alzheimer mutation produces increased A beta 42 deposition and severe cerebellar pathology. Nat Med 2:1146-1150.

Lesne S, Koh MT, Kotilinek L, Kayed R, Glabe CG, Yang A, Gallagher M, Ashe KH (2006) A specific amyloid-beta protein assembly in the brain impairs memory. Nature 440:352-357.

Levy E, Carman MD, Fernandez-Madrid IJ, Power MD, Lieberburg I, van Duinen SG, Bots GT, Luyendijk W, Frangione B (1990) Mutation of the Alzheimer's disease amyloid gene in hereditary cerebral hemorrhage, Dutch type. Science 248:1124-1126.

Lewis J, Dickson DW, Lin WL, Chisholm L, Corral A, Jones G, Yen SH, Sahara N, Skipper L, Yager D, Eckman C, Hardy J, Hutton M, McGowan E (2001) Enhanced neurofibrillary degeneration in transgenic mice expressing mutant tau and APP. Science 293:1487-1491.

Li M, Chen L, Lee DH, Yu LC, Zhang Y (2007) The role of intracellular amyloid beta in Alzheimer's disease. Prog Neurobiol 83:131-139.

Li WP, Chan WY, Lai HW, Yew DT (1997) Terminal dUTP nick end labeling (TUNEL) positive cells in the different regions of the brain in normal aging and Alzheimer patients. J Mol Neurosci 8:75-82.

Li YP, Bushnell AF, Lee CM, Perlmutter LS, Wong SK (1996) Beta-amyloid induces apoptosis in human-derived neurotypic SH-SY5Y cells. Brain Res 738:196-204.

Lippa CF, Hamos JE, Pulaski-Salo D, DeGennaro LJ, Drachman DA (1992) Alzheimer's disease and aging: effects on perforant pathway perikarya and synapses. Neurobiol Aging 13:405-411.

Loo DT, Copani A, Pike CJ, Whitemore ER, Walencewica Aj, Cotman CW (1993) Apoptosis is induced by beta-amyloid in cultured central nervous system neurons. Proc Natl Acad Sci USA 90:7951-7955.

Lorenzo A, Yankner BA (1994a) Beta-amyloid neurotoxicity requires fibril formation and is inhibited by congo red. Proc Natl Acad Sci U S A 91:12243-12247.

Lorenzo A, Yankner BA (1994b) Beta-amyloid neurotoxicity requires fibril formation and is inhibited by congo red. Proc Natl Acad Sci U S A 91:12243-12247.

Lorenzo A, Yankner BA (1996) Amyloid fibril toxicity in Alzheimer's disease and diabetes. Ann N Y Acad Sci 777:89-95.

Lott IT, Head E (2001) Down syndrome and Alzheimer's disease: a link between development and aging. Ment Retard Dev Disabil Res Rev 7:172-178. 
Madani R, Nef S, Vassalli JD (2003) Emotions are building up in the field of extracellular proteolysis. Trends Mol Med 9:183-185.

Malchiodi-Albedi F, Paradisi S, Matteucci A, Frank C, Diociaiuti M (2011) Amyloid oligomer neurotoxicity, calcium dysregulation, and lipid rafts. Int J Alzheimers Dis 2011:906964.

Mann DM, Brown A, Wilks DP, Davies CA (1989) Immunocytochemical and lectin histochemical studies of plaques and tangles in Down's syndrome patients at different ages. Prog Clin Biol Res 317:849-856.

Mann DMA, Yates PO, Marcynuik B (1985) Some morphometric observations on the cerebral cortex and hippocampus in presenile Alzheimer's disease, senile dementia of Alzheimer's type and Down's syndrome in middle age. J Neurol Sci 69:139-159.

Marques MA, Kulstad JJ, Savard CE, Green PS, Lee SP, Craft S, Watson GS, Cook DG (2009) Peripheral amyloid-beta levels regulate amyloid-beta clearance from the central nervous system. J Alzheimers Dis 16:325-329.

Martin BL, Schrader-Fischer G, Busciglio J, Duke M, Paganetti P, Yankner BA (1995) Intracellular accumulation of beta-amyloid in cells expressing the Swedish mutant amyloid precursor protein. J Biol Chem 270:26727-26730.

Masliah E (2001) Recent advances in the understanding of the role of synaptic proteins in Alzheimer's Disease and other neurodegenerative disorders. J Alzheimers Dis 3:121-129.

Masliah E, Terry RD, DeTeresa RM, Hansen LA (1989) Immunohistochemical quantification of the synapse-related protein synaptophysin in Alzheimer disease. Neurosci Lett 103:234-239.

Masliah E, Sisk A, Mallory M, Mucke L, Schenk D, Games D (1996) Comparison of neurodegenerative pathology in transgenic mice overexpressing V717F betaamyloid precursor protein and Alzheimer's disease. J Neurosci 16:5795-5811.

Masliah E, Rockenstein E, Veinbergs I, Sagara Y, Mallory M, Hashimoto M, Mucke L (2001a) beta-amyloid peptides enhance alpha-synuclein accumulation and neuronal deficits in a transgenic mouse model linking Alzheimer's disease and Parkinson's disease. Proc Natl Acad Sci U S A 98:12245-12250.

Masliah E, Mallory M, Alford M, DeTeresa R, Hansen LA, McKeel DW, Jr., Morris JC (2001b) Altered expression of synaptic proteins occurs early during progression of Alzheimer's disease. Neurology 56:127-129.

Masters CL, Simms G, Weinman NA, Multhaup G, McDonald BL, Beyreuther K (1985) Amyloid plaque core protein in Alzheimer disease and Down syndrome. Proc Natl Acad Sci USA 82:4245-4249.

Matsuoka Y, Saito M, LaFrancois J, Gaynor K, Olm V, Wang L, Casey E, Lu Y, Shiratori C, Lemere C, Duff K (2003) Novel therapeutic approach for the treatment of Alzheimer's disease by peripheral administration of agents with an affinity to betaamyloid. J Neurosci 23:29-33.

Mattson MP, Cheng B, Davis D, Bryant K, Lieberburg I, Rydel RE (1992) beta-Amyloid peptides destabilize calcium homeostasis and render human cortical neurons vulnerable to excitotoxicity. J Neurosci 12:376-389.

Mattson MP, Barger SW, Cheng B, Lieberburg I, Smith-Swintosky VL, Rydel RE (1993a) beta-Amyloid precursor protein metabolites and loss of neuronal $\mathrm{Ca} 2+$ homeostasis in Alzheimer's disease. Trends Neurosci 16:409-414. 
Mattson MP, Cheng B, Culwell AR, Esch FS, Lieberburg I, Rydel RE (1993b) Evidence for excitoprotective and intraneuronal calcium-regulating roles for secreted forms of the beta-amyloid precursor protein. Neuron 10:243-254.

McDermott JR, Gibson AM (1997) Degradation of Alzheimer's beta-amyloid protein by human and rat brain peptidases: involvement of insulin-degrading enzyme. Neurochem Res 22:49-56.

McGeer EG, McGeer PL (1999) Brain inflammation in Alzheimer disease and the therapeutic implications. Curr Pharm Des 5:821-836.

McGeer PL (2000) Cyclo-oxygenase-2 inhibitors: rationale and therapeutic potential for Alzheimer's disease. Drugs Aging 17:1-11.

McGeer PL, Kawamata T, McGeer EG (1998) Localization and possible functions of presenilins in brain. Rev Neurosci 9:1-15.

McKhann G, Drachman D, Folstein M, Katzman R, Price DL, Stadlan EM (1984) Clinical diagnosis of Alzheimer's disease: report of the NINCDS-ADRDA Work Group under the auspices of Department of Health and Human Services Task Force on Alzheimer's disease. Neurology 34:939-944.

Merker K, Stolzing A, Grune T (2001) Proteolysis, caloric restriction and aging. Mech Ageing Dev 122:595-615.

Mesulam MM (1986) Alzheimer plaques and cortical cholinergic innervation. Neuroscience 17:275-276.

Mesulam MM, Geula C (1988) Acetychollinesterase-rich pyramidal neurons in the human neocortex and hippocampus: absence at birth, development during the life span, and dissolution in Alzheimer's disease. Ann Neurol 24:765-773.

Michaelis ML, Dobrowsky RT, Li G (2002) Tau neurofibrillary pathology and microtubule stability. J Mol Neurosci 19:289-293.

Mirsky IA, Kaplan S, Broh-Kahn RH (1949) Persinogen excretion (uropepsin as an index of the influence of various life situations on gastric secretion. Res Publ Assoc Res Nerv Ment Dis 29:628-646.

Monsonego A, Imitola J, Zota V, Oida T, Weiner HL (2003) Microglia-Mediated Nitric Oxide Cytotoxicity of T Cells Following Amyloid beta-Peptide Presentation to Th1 Cells. J Immunol 171:2216-2224.

Morgan D, Diamond DM, Gottschall PE, Ugen KE, Dickey C, Hardy J, Duff K, Jantzen P, DiCarlo G, Wilcock D, Connor K, Hatcher J, Hope C, Gordon M, Arendash GW (2000) A beta peptide vaccination prevents memory loss in an animal model of Alzheimer's disease. Nature 408:982-985.

Mori H, Takio k, Ogawara M, Selkie D (1992) Mass spectrometry of purified amyloid b protein in Alzheimer's disease. J Biol Chem 267:17082-17086.

Morris JC, McKeel DWJ, Storandt M, Rubin EH, Price JL, Grant EA, Ball MJ, Berg L (1991) Very mild Alzheimer's disease: informant-based clinical, psychometric, and pathologic distinction from normal aging. Neurology 41:469-478.

Nagele RG, D'Andrea MR, Anderson WJ, Wang HY (2002) Intracellular accumulation of beta-amyloid (1-42) in neurons is facilitated by the alpha7 nicotinic acetylcholine receptor in Alzheimer's disease. Neuroscience 110:199-211.

Narain Y, Yip A, Murphy T, Brayne C, Easton D, Evans JG, Xuereb J, Cairns N, Esiri MM, Furlong RA, Rubinsztein DC (2000) The ACE gene and Alzheimer's disease susceptibility. J Med Genet 37:695-697. 
Ng DT, Spear ED, Walter P (2000) The unfolded protein response regulates multiple aspects of secretory and membrane protein biogenesis and endoplasmic reticulum quality control. J Cell Biol 150:77-88.

Nicolau C, Greferath R, Balaban TS, Lazarte JE, Hopkins RJ (2002) A liposome-based therapeutic vaccine against beta -amyloid plaques on the pancreas of transgenic NORBA mice. Proc Natl Acad Sci U S A 99:2332-2337.

Nilsberth C, Westlind-Danielsson A, Eckman CB, Condron MM, Axelman K, Forsell C, Stenh C, Luthman J, Teplow DB, Younkin SG, Naslund J, Lannfelt L (2001) The 'Arctic' APP mutation (E693G) causes Alzheimer's disease by enhanced Abeta protofibril formation. Nat Neurosci 4:887-893.

Okamoto I, Kawano Y, Murakami D, Sasayama T, Araki N, Miki T, Wong AJ, Saya H (2001) Proteolytic release of CD44 intracellular domain and its role in the CD44 signaling pathway. J Cell Biol 155:755-762.

Papassotiropoulos A, Bagli M, Feder O, Jessen F, Maier W, Rao ML, Ludwig M, Schwab SG, Heun R (1999) Genetic polymorphism of cathepsin D is strongly associated with the risk for developing sporadic Alzheimer's disease. Neurosci Lett 262:171-174.

Paradis E, Douillard H, Koutroumanis M, Goodyer C, LeBlanc A (1996) Amyloid beta peptide of Alzheimer's disease downregulates $\mathrm{Bcl}-2$ and upregulates bax expression in human neurons. J Neurosci 16:7533-7539.

Park JH, Strittmatter SM (2007) Nogo receptor interacts with brain APP and Abeta to reduce pathologic changes in Alzheimer's transgenic mice. Curr Alzheimer Res 4:568-570.

Pearson RC, Powell TP (1987) Anterograde vs. retrograde degeneration of the nucleus basalis medialis in Alzheimer's disease. J Neural Transm Suppl 24:139-146.

Perez A, Morelli L, Cresto JC, Castano EM (2000) Degradation of soluble amyloid betapeptides 1-40, 1-42, and the Dutch variant 1-40Q by insulin degrading enzyme from Alzheimer disease and control brains. Neurochem Res 25:247-255.

Pike CJ, Walencewicz AJ, Glabe CG, Cotman CW (1991) In vitro aging of beta-amyloid protein causes peptide aggregation and neurotoxicity. Brain Res 563:311-314.

Podlisny MB, Lee G, Selkoe DJ (1987) Gene dosage of the amyloid beta precursor protein in Alzheimer's disease. Science 238:669-671.

Podlisny MB, Stephenson DT, Frosch MP, Tolan DR, Lieberburg I, Clemens JA, Selkoe DJ (1993) Microinjection of synthetic amyloid beta-protein in monkey cerebral cortex fails to produce acute neurotoxicity. Am J Pathol 142:17-24.

Podlisny MB, Walsh DM, Amarante P, Ostaszewski BL, Stimson ER, Maggio JE, Teplow DB, Selkoe DJ (1998) Oligomerization of endogenous and synthetic amyloid betaprotein at nanomolar levels in cell culture and stabilization of monomer by Congo red. Biochemistry 37:3602-3611.

Poduslo JF, Curran GL, Kumar A, Frangione B, Soto C (1999) Beta-sheet breaker peptide inhibitor of Alzheimer's amyloidogenesis with increased blood-brain barrier permeability and resistance to proteolytic degradation in plasma. J Neurobiol 39:371-382.

Pollack SJ, Sadler, II, Hawtin SR, Tailor VJ, Shearman MS (1995) Sulfonated dyes attenuate the toxic effects of beta-amyloid in a structure-specific fashion. Neurosci Lett 197:211-214.

Ponte P, Gonzalez-Dewhittt P, Schilling J, Miller J, Hsu D, Greenberg B, Davis K, Wallace W, Lieberburg I, Fuller F (1988) A new A4 amyloid mRNA contains a domain homologous to serine proteinase inhibitors. Nature 331:525-527. 
Poorkaj P, Bird TD, Wijsman E, Nemens E, Garruto RM, Anderson L, Andreadis A, Wiederholt WC, Raskind M, Schellenberg GD (1998) Tau is a candidate gene for chromosome 17 frontotemporal dementia. Ann Neurol 43:815-825.

Price DL, Sisodia SS (1998) Mutant genes in familial Alzheimer's disease and transgenic models. Annu Reve Neurosci 21:479-505.

Price DL, Sisodia SS, Gandy SE (1995) Amyloid beta amyloidosis in Alzheimer's disease. Curr Opin Neurol 8:268-274.

Price JL, McKeel DW, Jr., Morris JC (2001) Synaptic loss and pathological change in older adults--aging versus disease? Neurobiol Aging 22:351-352.

Ray WJ, Yao M, Nowotny P, Mumm J, Zhang W, Wu JY, Kopan R, Goate AM (1999) Evidence for a physical interaction between presenilin and Notch. Proc Natl Acad Sci U S A 96:3263-3268.

Roder H (2003) Prospect of therapeutic approaches to tauopathies. J Mol Neurosci 20:195202.

Rogaev EI, Sherrington R, Rogaeva EA, Levesque G, Ikeda M, Liang Y, Chi H, Lin C, Holman K, Tsuda T, et al. (1995) Familial Alzheimer's disease in kindreds with missense mutations in a gene on chromosome 1 related to the Alzheimer's disease type 3 gene. Nature 376:775-778.

Rogers J, Luber-Narod J, Styren SD, Civin WH (1988) Expression of immune systemassociated antigens by cells of the human central nervous system: relationship to the pathology of Alzheimer's disease. Neurobiol Aging 9:339-349.

Roher A, Lowenson J, Clarke S, Woods S, Cotter R, Gowing E, Ball MJ (1993) beta-Amyloid(1-42) is a major component of cerebrovascular amyloid deposits: implications for the pathology of Alzheimer's disease. Proc Natl Acad Sci USA 90:10836-10840.

Roher AE, Chaney MO, Kuo YM, Webster SD, Stine WB, Haverkamp LJ, Woods AS, Cotter RJ, Tuohy JM, Krafft GA, Bonnell BS, Emmerling MR (1996) Morphology and toxicity of Abeta-(1-42) dimer derived from neuritic and vascular amyloid deposits of Alzheimer's disease. J Biol Chem 271:20631-20635.

Roses AD (1996) The Alzheimer diseases. Curr Opin Neurobiol 6:644-650.

Sagare A, Deane R, Bell RD, Johnson B, Hamm K, Pendu R, Marky A, Lenting PJ, Wu Z, Zarcone T, Goate A, Mayo K, Perlmutter D, Coma M, Zhong Z, Zlokovic BV (2007) Clearance of amyloid-beta by circulating lipoprotein receptors. Nat Med 13:10291031.

Salminen A, Ojala J, Suuronen T, Kaarniranta K, Kauppinen A (2008) Amyloid-beta oligomers set fire to inflammasomes and induce Alzheimer's pathology. J Cell Mol Med 12:2255-2262.

Salomon AR, Marcinowski KJ, Friedland RP, Zagorski MG (1996) Nicotine inhibits amyloid formation by the beta-peptide. Biochemistry 35:13568-13578.

Samuel W, Masliah E, Hill LR, Butters N, Terry R (1994) Hippocampal connectivity and Alzheimer's dementia: effects of synapse loss and tangle frequency in a twocomponent model. Neurology 44:2081-2088.

Sato M, Ikeda K, Haga S, Allsop D, Ishii T (1991) A monoclonal antibody to common acute lymphoblastic leukemia antigen (neutral endopeptidase) immunostains senile plaques in the brains of patients with Alzheimer's disease. Neurosci Lett 121:271273.

Satoh J, Kuroda Y (2001) Nicastrin, a key regulator of presenilin function, is expressed constitutively in human neural cell lines. Neuropathology 21:115-122. 
Scheff SW, Price DA (2001) Alzheimer's disease-related synapse loss in the cingulate cortex. J Alzheimers Dis 3:495-505.

Scheff SW, Price DA, Sparks DL (2001) Quantitative assessment of possible age-related change in synaptic numbers in the human frontal cortex. Neurobiol Aging 22:355365.

Schenk D et al. (1999) Immunization with amyloid-beta attenuates Alzheimer-disease-like pathology in the PDAPP mouse. Nature 400:173-177.

Scheuner D et al. (1996) Secreted amyloid beta-protein similar to that in the senile plaques of Alzheimer's disease is increased in vivo by the presenilin 1 and 2 and APP mutations linked to familial Alzheimer's disease. Nat Med 2:864-870.

Schwartz JC, de la Baume S, Malfroy B, Patey G, Perdrisot R, Swerts JP, Fournie-Zaluski MC, Gacel G, Roques BP (1980) "Enkephalinase", a newly characterised dipeptidyl carboxypeptidase: properties and possible role in enkephalinergic transmission. Int J Neurol 14:195-204.

Selkoe DJ (2001) Clearing the brain's amyloid cobwebs. Neuron 32:177-180.

Selkoe DJ (2002) Alzheimer's disease is a synaptic failure. Science 298:789-791.

Selkoe DJ (2007) Developing preventive therapies for chronic diseases: lessons learned from Alzheimer's disease. Nutr Rev 65:S239-243.

Shankar GM, Leissring MA, Adame A, Sun X, Spooner E, Masliah E, Selkoe DJ, Lemere CA, Walsh DM (2009) Biochemical and immunohistochemical analysis of an Alzheimer's disease mouse model reveals the presence of multiple cerebral Abeta assembly forms throughout life. Neurobiol Dis 36:293-302.

Sherrington R et al. (1996) Alzheimer's disease associated with mutations in presenilin 2 is rare and variably penetrant. Hum Mol Genet 5:985-988.

Shibata M, Yamada S, Kumar SR, Calero M, Bading J, Frangione B, Holtzman DM, Miller CA, Strickland DK, Ghiso J, Zlokovic BV (2000) Clearance of Alzheimer's amyloidss(1-40) peptide from brain by LDL receptor-related protein-1 at the blood-brain barrier. J Clin Invest 106:1489-1499.

Siman R, Flood DG, Thinakaran G, Neumar RW (2001) Endoplasmic reticulum stressinduced cysteine protease activation in cortical neurons: effect of an Alzheimer's disease-linked presenilin-1 knock-in mutation. J Biol Chem 276:44736-44743.

Simons K, Gerl MJ (2010) Revitalizing membrane rafts: new tools and insights. Nat Rev Mol Cell Biol 11:688-699.

Sinha S, Lieberburg I (1999) Cellular mechanisms of beta-amyloid production and secretion. Proc Natl Acad Sci USA 96:11049-11053.

Sisodia SS, Koo EH, Hoffman PN, Perry G, Price DL (1993) Identification and transport of full-length amyloid precursor proteins in rat peripheral nervous system. J Neurosci 13:3136-3142.

Smale G, Nichols NR, Brady DR, Finch CE, Horton WEJ (1995) Evidence for apoptotic cell death in Alzheimer's disease. Exp Neurol 133:225-230.

Smith MJ, Kwok JB, McLean CA, Kril JJ, Broe GA, Nicholson GA, Cappai R, Hallupp M, Cotton RG, Masters CL, Schofield PR, Brooks WS (2001) Variable phenotype of Alzheimer's disease with spastic paraparesis. Ann Neurol 49:125-129.

Song ES, Juliano MA, Juliano L, Hersh LB (2003) Substrate activation of insulin-degrading enzyme (insulysin). A potential target for drug development. J Biol Chem 278:49789-49794. 
Soto C, Kindy MS, Baumann M, Frangione B (1996) Inhibition of Alzheimer's amyloidosis by peptides that prevent beta-sheet conformation. Biochem Biophys Res Commun 226:672-680.

Soto C, Sigurdsson EM, Morelli L, Kumar RA, Castano EM, Frangione B (1998) Beta-sheet breaker peptides inhibit fibrillogenesis in a rat brain model of amyloidosis: implications for Alzheimer's therapy. Nat Med 4:822-826.

Spillantini MG, Goedert M (1998) Tau protein pathology in neurodegenerative diseases. Trends Neurosci 21:428-433.

Stephan A, Laroche S, Davis S (2001) Generation of aggregated beta-amyloid in the rat hippocampus impairs synaptic transmission and plasticity and causes memory deficits. J Neurosci 21:5703-5714.

Stern DM, Yan SD, Yan SF, Schmidt AM (2002) Receptor for advanced glycation endproducts (RAGE) and the complications of diabetes. Ageing Res Rev 1:1-15.

Strooper BD, Annaert W (2001) Presenilins and the intramembrane proteolysis of proteins: facts and fiction. Nat Cell Biol 3:E221-225.

Struble RG, Kitt CA, Walker LC, Cork LC, Price DL (1984) Somatostatinergic neurites in senile plaques of aged non-human primates. Brain Res 324:394-396.

Struble RG, Lehmann J, Mitchell SJ, McKinney M, Price DL, Coyle JT, DeLong MR (1986) Basal forebrain neurons provide major cholinergic innervation of primate neocortex. Neurosci Lett 66:215-220.

Su JH, Deng G, Cotman CW (1997) Bax protein expression is increased in Alzheimer's brain: correlations with DNA damage, Bcl-2 expression, and brain pathology. J Neuropathol Exp Neurol 56:86-93.

Sugarman MC, Yamasaki TR, Oddo S, Echegoyen JC, Murphy MP, Golde TE, Jannatipour M, Leissring MA, LaFerla FM (2002) Inclusion body myositis-like phenotype induced by transgenic overexpression of beta APP in skeletal muscle. Proc Natl Acad Sci U S A 99:6334-6339.

Tabira T, Chui DH, Kuroda S (2002) Significance of intracellular Abeta42 accumulation in Alzheimer's disease. Front Biosci 7:a44-49.

Takahashi RH, Milner TA, Li F, Nam EE, Edgar MA, Yamaguchi H, Beal MF, Xu H, Greengard P, Gouras GK (2002) Intraneuronal Alzheimer abeta42 accumulates in multivesicular bodies and is associated with synaptic pathology. Am J Pathol 161:1869-1879.

Takashima A, Sato M, Mercken M, Tanaka S, Kondo S, Honda T, Sato K, Murayama M, Noguchi K, Nakazato Y, Takahashi H (1996) Localization of Alzheimer-associated presenilin 1 in transfected COS-7 cells. Biochem Biophys Res Commun 227:423-426.

Tandon A, Fraser P (2002) The presenilins. Genome Biol 3:reviews3014.

Tang BL, Liou YC (2007) Novel modulators of amyloid-beta precursor protein processing. J Neurochem 100:314-323.

Tanimukai H, Sato K, Kudo T, Kashiwagi Y, Tohyama M, Takeda M (1999) Regional distribution of presenilin-1 messenger RNA in the embryonic rat brain: comparison with beta-amyloid precursor protein messenger RNA localization. Neuroscience 90:27-39.

Tanzi RE, Moir RD, Wagner SL (2004) Clearance of Alzheimer's Abeta peptide: The many roads to perdition. Neuron 43:605-608. 
Tekirian TL, Cole GM, Russell MJ, Yang F, Wekstein DR, Patel E, Snowdon DA, Markesbery WR, Geddes JW (1996) Carboxy terminal of beta-amyloid deposits in aged human, canine, and polar bear brains. Neurobiol Aging 17:249-257.

Terry RD (2000) Cell death or synaptic loss in Alzheimer disease. J Neuropathol Exp Neurol 59:1118-1119.

Terry RD, Masliah E, Salmon DP (1991) Physical basis of cognitive alterations in Alzheimer's disease: Synaptic loss is a major correlate of cognitive impairment. Ann Neurol 30:572-580.

Tienari PJ, Ida N, Ikonen E, Simons M, Weidemann A, Multhaup G, Masters CL, Dotti CG, Beyreuther K (1997) Intracellular and secreted Alzheimer beta-amyloid species are generated by distinct mechanisms in cultured hippocampal neurons. Proc Natl Acad Sci U S A 94:4125-4130.

Tomiyama T, Shoji A, Kataoka K, Suwa Y, Asano S, Kaneko H, Endo N (1996) Inhibition of amyloid beta protein aggregation and neurotoxicity by rifampicin. Its possible function as a hydroxyl radical scavenger. J Biol Chem 271:6839-6844.

Townsend M, Cleary JP, Mehta T, Hofmeister J, Lesne S, O'Hare E, Walsh DM, Selkoe DJ (2006) Orally available compound prevents deficits in memory caused by the Alzheimer amyloid-beta oligomers. Ann Neurol 60:668-676.

Troncoso JC, Sukhov RR, Kawas CH, Koliatsos VE (1996) In situ labeling of dying cortical neurons in normal aging and in Alzheimer's disease: correlations with senile plaques and disease progression. J Nuropathol Exp Neurol 55:1134-1142.

Tseng BP, Esler WP, Clish CB, Stimson ER, Ghilardi JR, Vinters HV, Mantyh PW, Lee JP, Maggio JE (1999) Deposition of monomeric, not oligomeric, Abeta mediates growth of Alzheimer's disease amyloid plaques in human brain preparations. Biochemistry 38:10424-10431.

Tsuzuki K, Fukatsu R, Yamaguchi H, Tateno M, Imai K, Fujii N, Yamauchi T (2000) Transthyretin binds amyloid beta peptides, Abeta1-42 and Abeta1-40 to form complex in the autopsied human kidney - possible role of transthyretin for abeta sequestration. Neurosci Lett 281:171-174.

Turner AJ, Tanzawa K (1997) Mammalian membrane metallopeptidases: NEP, ECE, KELL, and PEX. FASEB J 11:355-364.

Turner AJ, Isaac RE, Coates D (2001) The neprilysin (NEP) family of zinc metalloendopeptidases: genomics and function. Bioessays 23:261-269.

Urbanc B, Cruz L, Buldyrev SV, Havlin S, Irizarry MC, Stanley HE, Hyman BT (1999) Dynamics of plaque formation in Alzheimer's disease. Biophys J 76:1330-1334.

Van Uden E, Mallory M, Veinbergs I, Alford M, Rockenstein E, Masliah E (2002) Increased extracellular amyloid deposition and neurodegeneration in human amyloid precursor protein transgenic mice deficient in receptor-associated protein. J Neurosci 22:9298-9304.

VanSlyke JK, Musil LS (2002) Dislocation and degradation from the ER are regulated by cytosolic stress. J Cell Biol 157:381-394.

Vasilevko V, Xu F, Previti ML, Van Nostrand WE, Cribbs DH (2007) Experimental investigation of antibody-mediated clearance mechanisms of amyloid-beta in CNS of Tg-SwDI transgenic mice. J Neurosci 27:13376-13383.

Vassar R, Citron M (2000) Abeta-generating enzymes: recent advances in beta- and gammasecretase research. Neuron 27:419-422.

Vassar R et al. (1999) Beta-secretase cleavage of Alzheimer's amyloid precursor protein by the transmembrane aspartic protease BACE. Science 286:735-741. 
Walsh DM, Selkoe DJ (2007) A beta oligomers - a decade of discovery. J Neurochem 101:1172-1184.

Walsh DM, Tseng BP, Rydel RE, Podlisny MB, Selkoe DJ (2000) The oligomerization of amyloid beta-protein begins intracellularly in cells derived from human brain. Biochemistry 39:10831-10839.

Walsh DM, Klyubin I, Fadeeva JV, Rowan MJ, Selkoe DJ (2002a) Amyloid-beta oligomers: their production, toxicity and therapeutic inhibition. Biochem Soc Trans 30:552-557.

Walsh DM, Klyubin I, Fadeeva JV, Cullen WK, Anwyl R, Wolfe MS, Rowan MJ, Selkoe DJ (2002b) Naturally secreted oligomers of amyloid beta protein potently inhibit hippocampal long-term potentiation in vivo. Nature 416:535-539.

Walsh DM, Townsend M, Podlisny MB, Shankar GM, Fadeeva JV, El Agnaf O, Hartley DM, Selkoe DJ (2005a) Certain inhibitors of synthetic amyloid beta-peptide (Abeta) fibrillogenesis block oligomerization of natural Abeta and thereby rescue long-term potentiation. J Neurosci 25:2455-2462.

Walsh DM, Klyubin I, Shankar GM, Townsend M, Fadeeva JV, Betts V, Podlisny MB, Cleary JP, Ashe KH, Rowan MJ, Selkoe DJ (2005b) The role of cell-derived oligomers of Abeta in Alzheimer's disease and avenues for therapeutic intervention. Biochem Soc Trans 33:1087-1090.

Wang HY, D'Andrea MR, Nagele RG (2002) Cerebellar diffuse amyloid plaques are derived from dendritic Abeta42 accumulations in Purkinje cells. Neurobiol Aging 23:213223.

Wang SS, Rymer DL, Good TA (2001) Reduction in cholesterol and sialic acid content protects cells from the toxic effects of beta-amyloid peptides. J Biol Chem 276:42027-42034.

Waragai M, Imafuku I, Takeuchi S, Kanazawa I, Oyama F, Udagawa Y, Kawabata M, Okazawa H (1997) Presenilin 1 binds to amyloid precursor protein directly. Biochem Biophys Res Commun 239:480-482.

Wasco W, Bupp K, Magendantz M, Gusella JF, Tanzi RE, Solomon F (1992) Identification of a mouse brain cDNA that encodes a protein related to the Alzheimer diseaseassociated amyloid beta protein precursor. Proc Natl Acad Sci U S A 89:1075810762.

Weggen S, Eriksen JL, Das P, Sagi SA, Wang R, Pietrzik CU, Findlay KA, Smith TE, Murphy MP, Bulter T, Kang DE, Marquez-Sterling N, Golde TE, Koo EH (2001) A subset of NSAIDs lower amyloidogenic Abeta42 independently of cyclooxygenase activity. Nature 414:212-216.

Weidemann A, Paliga K, Durrwang U, Czech C, Evin G, Masters CL, Beyreuther K (1997) Formation of stable complexes between two Alzheimer's disease gene products: presenilin-2 and beta-amyloid precursor protein. Nat Med 3:328-332.

Weiner HL, Lemere CA, Maron R, Spooner ET, Grenfell TJ, Mori C, Issazadeh S, Hancock WW, Selkoe DJ (2000) Nasal administration of amyloid-beta peptide decreases cerebral amyloid burden in a mouse model of Alzheimer's disease. Ann Neurol 48:567-579.

Weinstock M (1997) Possible role of the cholinergic system and disease models. J Neural Transm Suppl 49:93-102.

Werb Z (1997) ECM and cell surface proteolysis: regulating cellular ecology. Cell 91:439-442.

Werner ED, Brodsky JL, McCracken AA (1996) Proteasome-dependent endoplasmic reticulum-associated protein degradation: an unconventional route to a familiar fate. Proc Natl Acad Sci U S A 93:13797-13801. 
West MJ, Coleman PS, Flood DG, Troncoso JC (1994) Differences in the pattern of hippocampal neuronal loss in normal aging and Alzheimer's disease. Lancet 344:769-772.

Whitehouse PJ, Price DL, Clark AW, Coyle JT, DeLong MR (1981) Alzheimer disease: evidence for selective loss of cholinergic neurons in the nucleus basalis. Ann Neurol 10:122-126.

Whitehouse PJ, Price DL, Struble RG, Clark AW, Coyle JT, Delon MR (1982) Alzheimer's disease and senile dementia: loss of neurons in the basal forebrain. Science 215:1237-1239.

Wirths O, Multhaup G, Czech C, Blanchard V, Moussaoui S, Tremp G, Pradier L, Beyreuther K, Bayer TA (2001) Intraneuronal Abeta accumulation precedes plaque formation in beta-amyloid precursor protein and presenilin-1 double-transgenic mice. Neurosci Lett 306:116-120.

Wisniewski T, Ghiso J, Frangione B (1997) Biology of A beta amyloid in Alzheimer's disease. Neurobiol Dis 4:313-328.

Wong PC, Zheng H, Chen H, Becher MW, Sirinathsinghi DJ, Trumbauer ME, Chen HY, Price DL, Van der Ploeg LH, Sisodia SS (1997) Presenilin 1 is required for Notch1 and DII1 expression in the paraxial mesoderm. Nature 387:288-292.

Xia W, Zhang J, Ostaszewski BL, Kimberly WT, Seubert P, Koo EH, Shen J, Selkoe DJ (1998) Presenilin 1 regulates the processing of beta-amyloid precursor protein C-terminal fragments and the generation of amyloid beta-protein in endoplasmic reticulum and Golgi. Biochemistry 37:16465-16471.

Yaar M, Zhai S, Fine RE, Eisenhauer PB, Arble BL, Stewart KB, Gilchrest BA (2002) Amyloid beta binds trimers as well as monomers of the $75-\mathrm{kDa}$ neurotrophin receptor and activates receptor signaling. J Biol Chem 277:7720-7725.

Yamada K, Yabuki C, Seubert P, Schenk D, Hori Y, Ohtsuki S, Terasaki T, Hashimoto T, Iwatsubo T (2009) Abeta immunotherapy: intracerebral sequestration of Abeta by an anti-Abeta monoclonal antibody 266 with high affinity to soluble Abeta. J Neurosci 29:11393-11398.

Yamada T, Sasaki H, Dohura K, Goto I, Sadadi Y (1989) Structure and expressionof the alternatively-spliced forms of mRNA for the mouse homolog of Alzheimer's disease amyloid beta protein precursor. Biochem Biophys Res Comm 158:906-912.

Yamaguchi H, Yamazaki T, Kawarabayashi T, Sun X, Sakai Y, Hirai S (1994) Localization of Alzheimer amyloid beta protein precursor and its relation to senile plaque amyloid. Gerontology 40:65-70.

Yamaguchi H, Ishiguro K, Shoji M, Yamazaki T, Nakazato Y, Ihara Y, Hirai S (1990) Amyloid beta/A4 protein precursor is bound to neurofibrillary tangles in Alzheimer-type dementia. Brain Res 537:318-322.

Yan SD, Chen X, Fu J, Chen M, Zhu H, Roher A, Slattery T, Zhao L, Nagashima M, Morser J, Migheli A, Nawroth P, Stern D, Schmidt AM (1996) RAGE and amyloid-beta peptide neurotoxicity in Alzheimer's disease. Nature 382:685-691.

Yan SD, Fu J, Soto C, Chen X, Zhu H, Al-Mohanna F, Collison K, Zhu A, Stern E, Saido T, Tohyama M, Ogawa S, Roher A, Stern D (1997) An intracellular protein that binds amyloid-beta peptide and mediates neurotoxicity in Alzheimer's disease. Nature 389:689-695.

Yang AJ, Chandswangbhuvana D, Margol L, Glabe CG (1998) Loss of endosomal/lysosomal membrane impermeability is an early event in amyloid Abeta1-42 pathogenesis. J Neurosci Res 52:691-698. 
Yankner BA (1996) Mechanisms of neuronal degeneration in Alzheimer's disease. Neuron 16:921-932.

Yankner BA, Caceres A, Duffy LK (1990) Nerve growth factor potentiates the neurotoxicity of beta amyloid. Proc Natl Acad Sci U S A 87:9020-9023.

Yao PJ, Morsch R, Callahan LM, Coleman PD (1999) Changes in synaptic expression of clathrin assembly protein AP180 in Alzheimer's disease analysed by immunohistochemistry. Neuroscience 94:389-394.

Yarr M, Zhai S, Pilch PF, Doyle SM, Eisenhauer PB, Fine RE, Gilchrest BA (1997) Binding of beta-amyloid to the p75 neurotrophin receptor induces apoptosis. A possible mechanism for Alzheimer's disease. J Clin Invest 100:2333-2340.

Yasojima K, Akiyama H, McGeer EG, McGeer PL (2001) Reduced neprilysin in high plaque areas of Alzheimer brain: a possible relationship to deficient degradation of betaamyloid peptide. Neurosci Lett 297:97-100.

Yong VW, Krekoski CA, Forsyth PA, Bell R, Edwards DR (1998) Matrix metalloproteinases and diseases of the CNS. Trends Neurosci 21:75-80.

Yu G et al. (2000) Nicastrin modulates presenilin-mediated notch/glp-1 signal transduction and betaAPP processing. Nature 407:48-54.

Zamani MR, Allen YS, Owen GP, Gray JA (1997) Nicotine modulates the neurotoxic effect of beta-amyloid protein(25-35)) in hippocampal cultures. Neuroreport 8:513-517.

Zerovnik E, Stoka V, Mirtic A, Guncar G, Grdadolnik J, Staniforth RA, Turk D, Turk V (2011) Mechanisms of amyloid fibril formation - focus on domain-swapping. FEBS J 278:2263-2282.

Zhang Y, McLaughlin R, Goodyer C, LeBlanc A (2002) Selective cytotoxicity of intracellular amyloid beta peptide1-42 through p53 and Bax in cultured primary human neurons. J Cell Biol 156:519-529.

Zhang Y, Champagne N, Beitel LK, Goodyer CG, Trifiro M, LeBlanc A (2004) Estrogen and androgen protection of human neurons against intracellular amyloid beta1-42 toxicity through heat shock protein 70. J Neurosci 24:5315-5321.

Zhang Y, Hong Y, Bounhar Y, Blacker M, Roucou X, Tounekti O, Vereker E, Bowers WJ, Federoff HJ, Goodyer CG, LeBlanc A (2003) p75 neurotrophin receptor protects primary cultures of human neurons against extracellular amyloid beta peptide cytotoxicity. J Neurosci 23:7385-7394.

Zheng H, Jiang M, Trumbauer ME, Hopkins R, Sirinathsinghji DJ, Stevens KA, Conner MW, Slunt HH, Sisodia SS, Chen HY, Van der Ploeg LH (1996) Mice deficient for the amyloid precursor protein gene. Ann N Y Acad Sci 777:421-426.

Zlokovic BV (1996) Cerebrovascular transport of Alzheimer's amyloid beta and apolipoproteins $\mathrm{J}$ and $\mathrm{E}$ : possible anti-amyloidogenic role of the blood-brain barrier. Life Sci 59:1483-1497.

Zlokovic BV (2008) New therapeutic targets in the neurovascular pathway in Alzheimer's disease. Neurotherapeutics 5:409-414. 


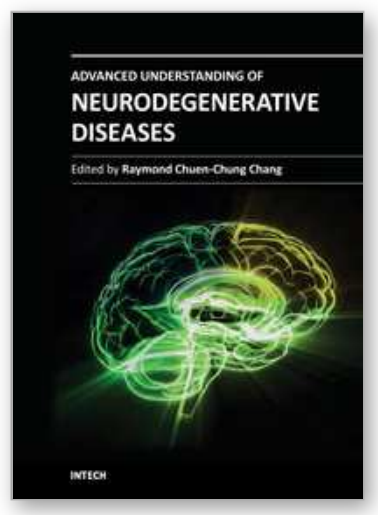

\author{
Advanced Understanding of Neurodegenerative Diseases \\ Edited by Dr Raymond Chuen-Chung Chang
}

ISBN 978-953-307-529-7

Hard cover, 442 pages

Publisher InTech

Published online 16, December, 2011

Published in print edition December, 2011

Advanced Understanding of Neurodegenerative Diseases focuses on different types of diseases, including Alzheimer's disease, frontotemporal dementia, different tauopathies, Parkinson's disease, prion disease, motor neuron diseases such as multiple sclerosis and spinal muscular atrophy. This book provides a clear explanation of different neurodegenerative diseases with new concepts of understand the etiology, pathological mechanisms, drug screening methodology and new therapeutic interventions. Other chapters discuss how hormones and health food supplements affect disease progression of neurodegenerative diseases. From a more technical point of view, some chapters deal with the aggregation of prion proteins in prion diseases. An additional chapter to discuss application of stem cells. This book is suitable for different readers: college students can use it as a textbook; researchers in academic institutions and pharmaceutical companies can take it as updated research information; health care professionals can take it as a reference book, even patients' families, relatives and friends can take it as a good basis to understand neurodegenerative diseases.

\title{
How to reference
}

In order to correctly reference this scholarly work, feel free to copy and paste the following:

Xiaqin Sun and Yan Zhang (2011). Amyloid Hypothesis and Alzheimer's Disease, Advanced Understanding of Neurodegenerative Diseases, Dr Raymond Chuen-Chung Chang (Ed.), ISBN: 978-953-307-529-7, InTech, Available from: http://www.intechopen.com/books/advanced-understanding-of-neurodegenerativediseases/amyloid-hypothesis-and-alzheimer-s-disease

\section{INTECH}

open science | open minds

\section{InTech Europe}

University Campus STeP Ri

Slavka Krautzeka 83/A

51000 Rijeka, Croatia

Phone: +385 (51) 770447

Fax: +385 (51) 686166

www.intechopen.com

\section{InTech China}

Unit 405, Office Block, Hotel Equatorial Shanghai

No.65, Yan An Road (West), Shanghai, 200040, China 中国上海市延安西路65号上海国际贵都大饭店办公楼 405 单元

Phone: +86-21-62489820

Fax: $+86-21-62489821$ 
(C) 2011 The Author(s). Licensee IntechOpen. This is an open access article distributed under the terms of the Creative Commons Attribution 3.0 License, which permits unrestricted use, distribution, and reproduction in any medium, provided the original work is properly cited. 